\title{
Preventive Effects of Selenium Yeast, Chromium Picolinate, Zinc Sulfate and their Combination on Oxidative Stress, Inflammation, Impaired Angiogenesis and Atherogenesis in Myocardial Infarction in Rats
}

\author{
Nouf M. AL-Rasheed ${ }^{1}$, Hala A. Attia ${ }^{1,2 *}$, Raeesa A. Mohamed ${ }^{3}$, Nawal M. Al-Rasheed ${ }^{1}$ and Maha Al-Amin ${ }^{1}$ \\ ${ }^{1}$ Department of Pharmacology and Toxicology, College of Pharmacy, King Saud University, Riyadh, Kingdom of Saudi \\ Arabia. ${ }^{2}$ Department of Biochemistry, Faculty of Pharmacy, Mansoura University, Mansoura, Egypt. ${ }^{3}$ Department of \\ Anatomy, College of Medicine, King Saud University, Riyadh, Kingdom of Saudi Arabia.
}

Received, August 7, 2013; Revised, December 28, 2013; Accepted, December 30, 2013; Published December 31 , 2013.

\begin{abstract}
Purpose: Accumulating evidences suggest a critical role of trace metal dyshemostasis in oxidative stress and cardiac dysfunction after myocardial infarction (MI). This study investigated the cardioprotective effects of selenium yeast (Se), chromium picolinate $\mathrm{Cr}(\mathrm{pic}) 3$, zinc sulfate $(\mathrm{Zn})$ and their combination on isoproterenol (ISO)-induced MI. Methods: Rats were divided into six groups: normal control, ISO control, Se-pretreated $(0.1 \mathrm{mg} / \mathrm{kg}), \mathrm{Cr}($ pic $) 3$-pretreated $(400 \mu \mathrm{g} / \mathrm{kg}), Z n$-pretreated $(30 \mathrm{mg} / \mathrm{kg})$ and metal combination-pretreated groups. All metals were administered for 28 days and at the 27 th day, MI was induced by subcutaneous injection of ISO $(85 \mathrm{mg} / \mathrm{kg})$ once for two consecutive days. Results: ISO control group showed hyperlipidemia, elevation of cardiac biomarkers and lipid peroxidation and increased immunostaining of p47 phox NADPH oxidase subunit in addition to decreased levels of glutathione (GSH), superoxide dismutase (SOD), catalase (CAT) and glutathione peroxidase (GPx). Cardiac levels of tumor necrosis factor- $\alpha$ (TNF- $\alpha$ ) were increased, while vascular endothelial growth factor (VEGF, the major angiogenic factor) was decreased. Pretreatment with Se normalized the cardiac enzymes, lipid peroxidation, GSH, SOD, CAT, GPx, TNF- $\alpha$ and VEGF $(P<0.001)$ and reduced the immunostaining of p47 phox subunit. However, Se failed to correct the dyslipidemia. $\mathrm{Cr}($ pic $) 3$ significantly improved lipid profile $(P<0.001)$ and all other biochemical deviations except for VEGF. Zn, but to lesser extent, reduced the oxidative damage and TNF- $\alpha$ levels and improved both dyslipidemia and angiogenesis. Combination therapy exhibited less prominent protection compared to individual metals. Conclusion: Daily supplementation with trace metals is promising for improving myocardial performance via preventing oxidative damage, induction of angiogenesis, anti-inflammatory and/or antihyperlipidemic mechanisms.
\end{abstract}

This article is open to POST-PUBLICATION REVIEW. Registered readers (see "For Readers") may comment by clicking on ABSTRACT on the issue's contents page.

\section{INTRODUCTION}

Although remarkable developments have been made in the treatment of cardiovascular disease, myocardial infarction (MI) remains the leading cause of death worldwide (1). MI is the acute condition of myocardial necrosis that occurs as a result of imbalance between coronary blood supply and myocardial demand (1). Lipid peroxidation and excessive production of reactive oxygen species (ROS), such as superoxide anions $\left(\mathrm{O}_{2}^{-{ }^{-}}\right)$and hydrogen peroxide $\left(\mathrm{H}_{2} \mathrm{O}_{2}\right)$, play a major role in the pathogenesis of MI (2). ROS directly injure the cell membrane and cause cell death. However, ROS also stimulate signal transduction to upregulate inflammatory cytokines, e.g. tumor necrosis factor$\alpha(\mathrm{TNF}-\alpha)$ in the ischemic region and surrounding myocardium. TNF- $\alpha$ systemically affects a number of mediators of the pathological process involved in MI. It inhibits myocardial contractility, induces apoptosis of cardiomyocytes and acts directly on the vascular endothelium as well as on cardiomyocytes to increase the adhesion of leukocytes during inflammation (3). Therefore, a therapeutic strategy that minimizes oxidative stress and inflammatory cytokine releases is a possible innovative approach to the prevention of MI $(1,2)$.

Corresponding Author: Hala A. Attia, Ph. D.; Department of Pharmacology and Toxicology, College of Pharmacy, King Saud University, Kingdom of Saudi Arabia; E-mail: halafetoh@yahoo.com, hsalem@ksu.edu.sa 
Among multiple sources of ROS, nicotinamide adenine dinucleotide phosphate (NADPH) oxidase plays an important role in the development of myocardial oxidative damage. NADPH oxidase is a major source of $\mathrm{O}_{2}{ }^{--}$generation which consequently accelerates the development and progression of cardiomyocyte hypertrophy and heart failure (4). Following MI, activation and increased expression of myocardial NADPH oxidase are mediated through the activation of the $\mathrm{p} 47 \mathrm{phox}$ subunit of the enzyme (5) resulting in increased production of ROS. The NADPH oxidase system represents therefore a potential therapeutic target to prevent oxidative damage and cardiac failure after MI.

One of the important tissue responses to ischemia is angiogenesis; the formation of new blood vessels from the pre-existing ones. Angiogenesis represents a compensatory mechanism that is essential for restoration of oxygen transport to ischemic areas via improvement of the blood supply to the affected tissues (6). In ischemic tissues, angiogenesis is mediated by the increase in expression of important growth factors, in particular, vascular endothelial growth factor (VEGF) (7) which is the most notable and characteristic angiogenic factor induced by hypoxia. Thus, therapeutic angiogenesis is a promising treatment for myocardial ischemia after MI by increased expression of VEGF. Nitric oxide (NO) is thought to be critical in signal transduction through the ischemic myocardium (8). Previous studies have found that VEGF acts through receptors in the endothelium to increase the production of $\mathrm{NO}$, and thus the activity of the two growth factors may be associated (9). It has been demonstrated that, NO promotes the survival of ischemic tissue by stimulating angiogenesis (10). To elucidate the relationship between NO production and angiogenesis, serum levels of $\mathrm{NO}$ and its correlation with cardiac VEGF levels were estimated in the present study.

Furthermore, the accumulation of lipids and alteration of lipoproteins play an important role in the pathology of MI (11). To achieve the greatest possible reduction in MI risk, treatment strategies should be aimed at reducing the increased levels of circulatory lipids and lipoproteins (11).

Reduced circulating levels of the trace elements; selenium (12-14), zinc (15-18) and chromium (19) are found in patients and experimental models of MI. The decrease in the serum levels of zinc and selenium was observed in patients with higher levels of cardiac biomarkers, which implies that trace element levels are related to the degree of myocardial damage and may play a role in the pathogenesis of ischemic heart disease $(13,18)$. Being essential metals integral to the activity of antioxidant enzymes, this nutrient imbalance triggers the development of oxidative stress and the production of ROS that overwhelm endogenous antioxidant defences (20). Hence, the supplementation of microminerals could be beneficial for the prevention of MI via antioxidant mechanisms.

In recent years, selenium (Se) research has attracted tremendous interest because of its important role in antioxidant seleno-enzymes, such as glutathione peroxidase (GPx) and thioredoxin reductase, which protect against oxidative stress (21). The anti-inflammatory $(14,22)$ and antihyperlipidemic $(23,24)$ effects of Se have been previously reported. To our knowledge, the effect of Se supplementation on the cardiac levels of VEGF has not been studied in infarcted rats. In the present study, we aimed to estimate the possible role of Se in the prevention of MI based on its antioxidant, anti-inflammatory and antihyprlipidemic effects. In addition, the possible angiogenic effects of Se were also examined. The findings from previously conducted clinical trial indicate no overall benefit of supplementation with Se alone in prevention of cardiovascular disease (25). Therefore, a combination of Se with other trace elements such as zinc and chromium was used to evaluate the possible synergistic effects. Selenium supplements are in two forms: inorganic mineral salts, typically sodium selenite or selenate, and organic forms such as Se-enriched yeasts (26). Among different forms of Se, Se yeast has been found to be the best bioavailable form being more effective than sodium selenite and selenate in increasing tissue Se retention $(27,28)$. Yeast-based selenium typically consists of Baker's yeast (Saccharomyces cerevisiae) appropriately cultured in the presence of an inorganic source of Se (usually $\mathrm{Se}(\mathrm{IV})$ ) that yeast can accumulate and metabolize into organic Se species, mostly selenomethionine nonspecifically incorporated into peptide chains. Hence, yeast represents a mean to obtain, at low cost, high quantities of Se under organic forms which have been reported to be less toxic than inorganic Se (27). AS it is the most 
valuable and concurrently safe supplementation, therefore, Se yeast was used in the present study as the source of Se.

Trivalent chromium is an essential trace metal that has been shown to lower oxidative stress and improve glucose and lipid metabolism (29-35). Chromium picolinate $\mathrm{Cr}(\mathrm{pic}) 3$ is a widely consumed and well absorbed form of trivalent chromium that is widely promoted as a dietary supplement for adjunctive therapy for Type 2 diabetes $(29,30) . \mathrm{Cr}(\mathrm{pic}) 3$ supplementation has the potential to reduce cellular oxidative stress $(30,31)$, levels of proinflammatory cytokines (32-34), blood cholesterol and triglycerides in diabetes $(26,32)$. Whereas $\mathrm{Cr}(\mathrm{pic}) 3$ has been extensively investigated in relation to carbohydrate and lipid metabolism, there are only a few studies devoted to the effects of $\mathrm{Cr}$ (pic) 3 on the cardiovascular system $(36,37)$. No data are available concerning whether $\mathrm{Cr}($ pic $) 3$ could elicit cardioprotective effects in rats with infracted hearts.

Zinc $(\mathrm{Zn})$ is an essential micronutrient that is integral to the activity of various metalloenzymes required for cellular functions. $\mathrm{Zn}$ has critical antiinflammatory, anti-atherogenic and antioxidant actions to protect against various oxidative stresses $(38,39)$. Since MI causes a significant oxidative stress and is often accompanied by hypozincaemia, which increases the susceptibility of the heart to oxidative damage, therefore, there is a strong rationale to consider the strategy of $\mathrm{Zn}$ supplementation to protect the heart against MI. Very little is also known about the cardioprotective role of $\mathrm{Zn}$ supplementation on MI in rats.

Isoproterenol (ISO), a $\beta$-adrenergic receptor agonist, has been found to cause severe stress in the myocardium, resulting in cardiac muscle cellular damage and ultimately necrosis (1). The metabolic and morphologic abnormalities produced by ISO in the heart of experimental animals are similar to those observed in human MI, therefore, ISOinduced myocardial injury serves as a wellstandardized model for human MI to study the beneficial effects of many drugs on cardiac function. The present study aimed to test whether supplementation with $\mathrm{Se}, \mathrm{Cr}(\mathrm{pic}) 3$, and $\mathrm{Zn}$ either alone or in combination, provides protection against ISO-induced MI. The underlying mechanisms such as anti-oxidative, anti-inflammatory and anti- hyperlipidemic effects as well as the induction of cardiac VEGF were evaluated.

\section{MATERIALS AND METHODS}

\section{Chemicals and trace elements}

Isoproterenol hydrochloride, zinc sulfate, thiobarbituric acid, Ellman's reagent (5, 5'dithiobis-(2-nitrobenzoic acid), sulfanilamide and $\mathrm{N}$-(1-naphthyl) ethylenediamine were purchased from Sigma-Aldrich Chemical Co. (St. Louis, Missouri, USA). The p47phox antibody (H-195:sc14015) was purchased from Santa Cruz Biotechnology, Inc. $\mathrm{Cr}$ (pic) 3 and selenium (as yeast), both in the tablet form were purchased from GNC ARMAL Co. (Riyadh, Saudi Arabia). The tablets were crushed and suspended in $1 \%$ gum Arabic solution in normal saline. All other chemicals used were of high analytical grade.

\section{Animals}

Male albino Wistar rats weighing $180-200 \mathrm{~g}$ were provided by the Experimental Animal Center of King Saud University, College of Pharmacy, Riyadh, KSA and housed in a room at $21-25^{\circ} \mathrm{C}$ and a $12 \mathrm{~h} \mathrm{light/dark} \mathrm{cycle.} \mathrm{The} \mathrm{animals} \mathrm{had} \mathrm{free}$ access to pellet food and tap water. The research was conducted in accordance with the National Institutes of Health Guide for Care and Use of Laboratory Animals and approved by the Animal Care Committee of King Saud University.

\section{Induction of myocardial injury}

Isoproterenol (ISO) was dissolved in normal saline and injected subcutaneously into rats $(85 \mathrm{mg} / \mathrm{kg})$ daily for 2 consecutive days to induce experimental MI (40).

\section{Experimental design}

The rats were randomly divided into the following six groups of ten rats each: Group 1, normal control rats administered 1\% gum Arabic in normal saline by oral gavage for 28 days; Group 2, ISO control group administered 1\% gum Arabic in normal saline orally for 28 days and subcutaneously injected with ISO $(85 \mathrm{mg} / \mathrm{kg}$ ) once every $24 \mathrm{~h}$ for 2 consecutive days starting on the 27th day; Groups 3 to 5 , rats pretreated with $0.1 \mathrm{mg} / \mathrm{kg}$ /day selenium (Selenium 200®, selenium $200 \mathrm{mg}$ tablet as selenium yeast, GNC) (41), $\mathrm{Cr}($ pic $) 3$ $(400 \mu \mathrm{g} / \mathrm{kg} /$ day $)$ (34) and zinc sulfate (30 $\mathrm{mg} / \mathrm{kg} /$ day) (42), respectively; and Group 6: rats pretreated with a combination of the tested trace 
elements at the same doses. The metals and their combination were administered by oral gavage for 28 days, and on the 27th day, MI was induced by subcutaneous injection of $85 \mathrm{mg} / \mathrm{kg}$ of ISO for two consecutive days. All rats fasted overnight but had free access to water on the 28th day. The metal doses in this study are similar to other reports utilizing rodents $(34,41,42-44)$. The dose of Se was the adequate dose (not low or high dose) which previously found to be therapeutically effective in both ischemic $(45,46)$ and non-ischemic conditions $(41,47,48)$ and as powerful antioxidant $(41,47$, 48). The recommended estimated adequate dietary intake range for $\mathrm{Cr} 3+$ for adults is $50-200 \mu \mathrm{g}$ /day and human studies have mostly used 400-1000 $\mu \mathrm{g}$ $\mathrm{Cr}^{3+}$ per day. Assuming an average $70 \mathrm{~kg}$ body weight, this would relate to an intake of nearly 8-15 $\mu \mathrm{g} \mathrm{Cr}{ }^{3+} / \mathrm{kg}$ body weight. The dose of $\mathrm{Cr}$ (pic)3used in this study is $400 \mu \mathrm{gCr}{ }^{3+} / \mathrm{kg}$ body weight of rat. Thus, $\mathrm{Cr}^{3+}$ supplementation dose used per body weight in the present rat study is much higher than that used in human clinical trials. Several studies have reported beneficial effects of supplemental $\mathrm{Cr}$ at levels higher than the upper limit of the suggested intake for $\operatorname{Cr}(29,30,34)$ with no signs of toxicity. Previous data also demonstrated a lack of toxicity of trivalent $\mathrm{Cr}$, at levels that are on a per $\mathrm{kg}$ basis, several thousand times the upper limit of the estimated safe and adequate daily dietary intake for humans (49). The level of $\mathrm{Cr}^{3+}$ supplementation dose in the present study can be considered pharmacological in comparison to chromium supplementation dose used in the literature for human studies. The dose of $\mathrm{Zn}$ sulfate was selected on the basis of the oral concentration capable of induction of metallothionin, ameliorating oxidative stress, increasing the SOD and/or inhibiting inflammation in the heart (42), liver (43) and colon (44) of rats.

\section{Blood sampling and heart processing:}

Two hours after the second dose of ISO, body weight was recorded, and all rats were anesthetized and sacrificed by cervical decapitation. Blood was collected, allowed to coagulate and centrifuged at $3000 \mathrm{rpm}$ for 15 minutes at $4^{\circ} \mathrm{C}$. The serum was divided into aliquots to be used for the determination of cardiac biomarkers (troponin and cardiac enzymes), NO and lipid profile (total cholesterol (TC), triglycerides (TG), low density lipoprotein-cholesterol (LDL-C) and high density lipoproteins-cholesterol (HDL-C). The hearts were removed, trimmed of connecting tissue and rinsed with ice-cold phosphate buffered saline (PBS; $\mathrm{pH}$ 7.4). The hearts were weighed to calculate the heart to the body weight ratio. These ratios were determined as indices of cardiac hypertrophy. The hearts were then kept at $-80^{\circ} \mathrm{C}$ for further homogenization. Some hearts were divided into two parts. The first part was kept at $-80^{\circ} \mathrm{C}$ for homogenization, and the second part was fixed with $4 \%$ formalin for histological and immunohistochemical sudies.

\section{Preparation of tissue homogenate}

Each frozen cardiac sample was homogenized in PBS solution (pH7.4) using a Teflon homogenizer and then centrifuged for $10 \mathrm{~min}$ at $4{ }^{\circ} \mathrm{C}$ to remove debris. The supernatant was divided into portions, deeply frozen at $-80^{\circ}$ for further determination of TNF- $\alpha$, VEGF and oxidative stress markers including malondialdehyde (MDA, an end product of lipid peroxidation), reduced glutathione (GSH), superoxide dismutase (SOD), catalase (CAT) and glutathione peroxidase (GPx).

\section{Biochemical studies}

\section{Determination of serum levels of $\mathrm{Se}, \mathrm{Cr}^{+3}$ and $\mathrm{Zn}$}

The serum levels of $\mathrm{Se}, \mathrm{Cr}^{+3}$ and $\mathrm{Zn}$ were determined at the Chemical Analysis Unit, King Saud University, Riyadh by flame atomic absorption spectrometry using an atomic absorption spectrophotometer (Shimadzu Corp., Kyoto, Japan). An aliquot of serum was tenfold diluted with deionized water and used for measurement of Se at $196 \mathrm{~nm}$ wavelength using a slit width of $1.0 \mathrm{~nm}$ and a lamp current of $15 \mathrm{~mA}, \mathrm{Cr}^{+3}$ was measured at wavelength $357.9 \mathrm{~nm}$ using a slit width of $0.2 \mathrm{~nm}$ and lamp current $7 \mathrm{~mA}$, while $\mathrm{Zn}$ was measured at $213.9 \mathrm{~nm}$, using a slit width of $1.0 \mathrm{~nm}$ and lamp current of $5 \mathrm{~mA}$. Se, $\mathrm{Cr}^{+3}$ and $\mathrm{Zn}$ Atomic Absorption Standard Solutions (Sigma-Aldrich) were diluted for calibration with deionized water to obtain $\mathrm{Se}, \mathrm{Cr}$ and $\mathrm{Zn}$ working standards of $0,0.5$, $1.00,2.00$ and $2.5 \mathrm{mg} / \mathrm{L}$. The levels of $\mathrm{Se}, \mathrm{Cr}^{+3}$ and $\mathrm{Zn}$ were obtained by extrapolation of the standard curve followed by multiplication with the dilution factor.

\section{Assay of serum troponin I, cardiac marker enzymes and lipid profile}

Cardiac troponin-I (cTnI) was measured with immunoassay kits (Biosource Europe S.A., Belgium) according to the manufacturer's instructions. The activities of total creatine kinase (CK), aspartate aminotransferase (AST) and lactate 
dehydrogenase $(\mathrm{LDH})$ were measured in serum using standard commercial kits (Randox Laboratory Ltd., UK). The activity of serum CK-MB isoenzyme was estimated using ELISA kits (Kamiya Biomedical Co., WA, USA). The concentrations of $\mathrm{TC}, \mathrm{TG}$ and HDL-C were measured using standard commercial kits purchased from Randox Laboratory Ltd.. LDL-C was calculated as follows: LDL-C $=\mathrm{TC}-\mathrm{TAG} / 5-\mathrm{HDL}$.

\section{Assessment of oxidative stress markers in cardiac homogenate}

MDA was quantified using thiobarbituric acid (TBA) assay as described by Ohkawa et al. (50). A mixture of $0.5 \mathrm{ml}$ of $0.6 \% \mathrm{TBA}, 1.25 \mathrm{ml}$ of $20 \%$ trichloroacetic acid (TCA) and $250 \mu \mathrm{l}$ of heart homogenate was heated for 30 minutes in a boiling water bath and then cooled and centrifuged at $4^{\circ} \mathrm{C}$. The absorbance of the developed pink-colored chromogen was measured at $535 \mathrm{~nm}$ against a reagent blank. GSH was estimated according to the method described by Moron et al. (51) using Ellman's reagent which reacts with a thiol group in the presence of a phosphate buffer $(\mathrm{pH} 8)$ and TCA. Briefly, a sample of heart homogenate was deproteinized by adding an equal volume of $25 \%$ TCA and then centrifuged at $4^{\circ} \mathrm{C}$ for 10 minutes. Next, $0.5 \mathrm{ml}$ of supernatant was added to $4.5 \mathrm{ml}$ of Ellman's reagent and the produced yellow color was measured at $412 \mathrm{~nm}$ against a reagent blank. The activities of myocardial SOD and GPx were measured using assay kit (Cayman, Michigan, USA) according to the manufacturer's instructions. CAT activity was estimated as the decomposition rate of hydrogen peroxide according to the method of Aebi (52). In brief, $50 \mu 1$ of heart homogenate was diluted with $5 \mathrm{ml}$ of phosphate buffer, and then $2 \mathrm{ml}$ of the diluted homogenate was mixed with $1 \mathrm{ml}$ hydrogen peroxide. The absorbance was read after 15 and 30 seconds at $240 \mathrm{~nm}$.

\section{Measurement of TNF- $\alpha$ and VEGF}

Cardiac levels of TNF- $\alpha$ and VEGF were determined by ELISA technique using Quantikine Immunoassay kits (R\&D Systems, Inc., USA).

\section{Measurement of serum nitrite}

Biologically produced NO is rapidly oxidized to the stable metabolites; nitrite and nitrate. Thus, nitrite concentrations can reflect NO production. Serum nitrite levels were measured colorimetrically using Griess reagent (53), which converts nitrite into a deep purple azo chromophore. Briefly, $100 \mu l$ of serum was added to $100 \mu 1$ of Griess reagent (1:1 mixture of $1 \%$ sulfanilamide in $2.5 \%$ orthophosphoric acid and $0.1 \%$ N-(1-naphthyl) ethylenediamine in distilled water). After 10 min. of color development at room temperature, the absorbance was measured at $540 \mathrm{~nm}$.

\section{Histopathological analysis}

A portion of some hearts was washed immediately with saline and then fixed in 4\% phosphatebuffered formalin solution ( $\mathrm{pH}$ 7.4) for $24 \mathrm{~h}$. The tissues were then dehydrated in ascending grades of ethyl alcohol and embedded with paraffin. Then, all heart tissues were sectioned at $4 \mathrm{~mm}$ thicknesses, stained with hematoxylin and eosin (H\&E) and examined by light microscopy.

\section{Immunohistochemistry of p47 phox subunit of NADPH oxidase}

Detection of p47 phox was used as an indicator of $\mathrm{O}_{2}{ }^{--}$generation through the activation of NADPH oxidase. For this purpose, immunostaining of paraffin sections was performed using streptavidinbiotinylated horseradish peroxidase method. The sections were deparaffinized and rehydrated, and then endogenous peroxidase activity was inhibited by $3 \% \mathrm{H}_{2} \mathrm{O}_{2}$ in distilled water for 5 minutes. Nonspecific binding of antibodies was blocked by incubation with protein block for 5 minutes, and then the sections were incubated with rabbit polyclonal p47-phox antibody diluted 1:250 for $1 \mathrm{~h}$ at room temperature. After washing with Tris buffer, the sections were incubated with biotinylated antirabbit IgG for 30 minutes. Sections were washed and then incubated with working solution of 3,3diaminobenzedine / substrate (Novocastra) for 10 minutes. Finally, the sections were washed in distilled water for 10 minutes, counterstained with Mayer's hematoxylin and mounted in DPX mounting medium. The stained sections were evaluated and photographed by using an Olympus BX51 bright field microscope equipped with an Olympus DP72 camera (Olympus Corporation, Japan). For negative control sections, the same procedure was followed with the omission of incubation in rabbit polyclonal anti-human p47phox.

\section{STATISTICAL ANALYSIS}

The results are expressed as the mean \pm SEM. Statistical comparisons between the groups were performed using one-way analysis of variance (ANOVA) followed by a Tukey-Kramer post hoc 
test. The correlation coefficient [r] was used to measure the mutual correspondence of two quantitative variables in the same studied group. Statistical analysis was conducted using Prism GraphPad software version 4 (San Diego, California, USA). $P$ values $<0.05$ were considered statistically significant.

\section{RESULTS}

\section{Mortality rate}

Among the ten rats in each group, four rats died in the ISO control group ( $40 \%$ mortality rate), two rats from $\mathrm{Zn}$-pretreated rats $(20 \%)$, one rat $(10 \%)$ from Se and the combination- pretreated group and $0 \%$ mortality in $\mathrm{Cr}$ (pic)3-pretreated rats. This rate was recorded 24 hour after the first dose of ISO. All alive rats were sacrificed 2-hours after the second dose.

\section{Levels of $\mathrm{Se}, \mathrm{Cr}^{+3}$ and $\mathrm{Zn}$}

The data in Table 1 shows that acute administration of ISO significantly decreased the serum levels of Se $(P<0.001), \mathrm{Cr}^{+3}(P<0.001)$ and $\mathrm{Zn}(P<0.01)$ in ISO-treated control rats compared with the normal control group. Pretreatment with Se significantly restored the normal levels of $\mathrm{Se}$ in the serum $(P<0.001)$, whereas no significant improvement in the $\mathrm{Cr}^{+3}$ or $\mathrm{Zn}$ levels was observed in comparison with the ISO control group. Rats pretreated with $\mathrm{Cr}$ (pic)3 demonstrated significantly higher levels of $\mathrm{Cr}^{+3}(P<0.001)$, whereas the $\mathrm{Zn}$ and Se levels did not improve significantly compared with the ISO control group. A significant reduction of the serum Se levels was observed in $\mathrm{Cr}$ (pic)3pretreated group in comparison with the groups pretreated with Se $(P<0.01)$ or $\mathrm{Zn}(P<0.05)$. Pretreatment with $\mathrm{Zn}$ significantly restored the normal levels of $\mathrm{Zn}(P<0.001)$, improved the levels of Se $(P<0.05)$ compared with the ISO control group, but didn't ameliorate the $\mathrm{Cr}^{+3}$ levels significantly. The combination group displayed significant rises in the serum levels of $\mathrm{Cr}^{+3}(P<0.01)$ and $\mathrm{Zn}(P<0.05)$ compared to ISO control rats. The levels of Se were significantly decreased in the combination-pretreated rats compared with the Sepretreated group $(P<0.05)$

\section{Effect of $\mathrm{Se}, \mathrm{Cr}(\mathrm{pic})_{3}, \mathrm{Zn}$ and their combination on the heart weight and heart to body weight ratio in ISO-induced $\mathrm{MI}$ in rats}

As shown in Table 2, the heart weight and heart to body weight ratio were significantly increased $(P<0.01, P<0.001$, respectively) in ISO control rats compared with normal controls. The heart to body weight ratio was significantly reduced by pretreatment with $\mathrm{Se}(P<0.001), \mathrm{Cr}$ (pic)3 $(P<0.01)$, $\mathrm{Zn} \quad(P<0.05)$ and their combination $(P<0.01)$ compared with control ISO-treated rats. The heart to body weight ratio was significantly lower in Sepretreated rats compared with those pretreated with $\mathrm{Zn}(P<0.01)$ and there was a non-significant reduction in the ratio in comparison with $\mathrm{Cr}$ (pic)3pretreated rats.

Table 1. Serum levels of selenium (Se), chromium $\left(\mathrm{Cr}^{+3}\right)$ and zinc $(\mathrm{Zn})$ in normal control, ISO control, and in ISO groups pretreated with $\mathrm{Se}, \mathrm{Cr}(\mathrm{pic}) 3, \mathrm{Zn}$ and their combination:

\begin{tabular}{|c|c|c|c|}
\hline Group & $\begin{array}{c}\mathrm{Se} \\
(\mathrm{mg} / \mathrm{L})\end{array}$ & $\begin{array}{c}\mathrm{Cr} \\
(\mathrm{mg} / \mathrm{L})\end{array}$ & $\begin{array}{c}\mathrm{Zn} \\
(\mathrm{mg} / \mathrm{L})\end{array}$ \\
\hline Normal control & $0.15^{\mathrm{a}} \pm 0.009$ & $1.58^{\mathrm{a}} \pm 0.06$ & $1.23^{\mathrm{a}} \pm 0.11$ \\
\hline ISO control & $0.090^{\mathrm{b}} \pm 0.004$ & $0.94^{\mathrm{b}} \pm 0.05$ & $0.8^{b} \pm 0.06$ \\
\hline $\mathrm{Se}+\mathrm{ISO}$ & $0.136^{\mathrm{a}, \mathrm{c}} \pm 0.004$ & $1.115^{b} \pm 0.15$ & $1.01^{\mathrm{b}} \pm 0.04$ \\
\hline $\mathrm{Cr}(\mathrm{pic}) 3+\mathrm{ISO}$ & $0.094^{\mathrm{b}, \mathrm{d}} \pm 0.0036$ & $1.39^{\mathrm{a}, \mathrm{c}} \pm 0.04$ & $0.88^{b} \pm 0.07$ \\
\hline $\mathbf{Z n}+\mathbf{I S O}$ & $0.12^{\mathrm{a}, \mathrm{c}} \pm 0.011$ & $1.067^{\mathrm{b}} \pm 0.14$ & $1.36^{\mathrm{a}, \mathrm{c}} \pm 0.1$ \\
\hline $\mathrm{Se}+\mathrm{Cr}(\mathrm{pic}) 3+\mathrm{Zn}+\mathrm{ISO}$ & $0.113^{\mathrm{b}, \mathrm{d}} \pm 0.008$ & $1.47^{\mathrm{a}, \mathrm{c}} \pm 0.09$ & $1.1^{\mathrm{a}} \pm 0.07$ \\
\hline
\end{tabular}

Data are expressed as the means \pm SEM. Group comparisons were performed using one-way ANOVA followed by the Tukey Krammer post hoc test; Different characters indicate a significant difference between groups in the same column; The same characters signify no significant difference between values. 
Effect of Se, $\operatorname{Cr}(\text { pic })_{3}, \mathrm{Zn}$ and their combination on cTnI and the activities of cardiac marker enzymes

The serum levels of cTnI and the activities of cardiac marker enzymes [CK, CK-MB isoenzyme, AST and LDH] increased significantly $(P<0.001)$ in the ISO-control group compared with the normal control group (Table 3). Pretreatment with Se, $\mathrm{Cr}$ (pic)3, $\mathrm{Zn}$ and their combination resulted in a highly significant reduction in cTnI, CK, CK-MB and LDH compared with the ISO control group $(P<0.001)$. The serum levels of AST were significantly reduced by pretreatment with $\mathrm{Se}$ $(P<0.001), \mathrm{Cr}(\mathrm{pic}) 3(P<0.01)$ and the combination $(P<0.05)$, whereas $\mathrm{Zn}$ pretreatment did not show a significant reduction in AST levels compared with the ISO control group. As shown in Table 3, rats pretreated with $\mathrm{Zn}$ had significantly higher levels of cTnI, CK, CK-MB, AST and LDH compared with the Se-pretreated group $(P<0.05 ; \quad P<0.01)$. Zn pretreated rats also displayed significantly elevated cTnI serum levels compared with $\mathrm{Cr}$ (pic) 3 group. In addition, the combination group showed higher LDH activities compared with the Se-pretreated group $(P<0.01)$. From the results of Table 3, it could be concluded that Se followed by $\mathrm{Cr}($ pic $) 3$ and the combination resulted in the best improvement of serum cardiac biomarkers.
Effect of $\mathrm{Se}, \mathrm{Cr}(\mathrm{pic})_{3}, \mathrm{Zn}$ and their combination on oxidative stress markers in ISO-induced MI in rats

The effect on MDA concentration

Cardiac levels of MDA were significantly higher in the ISO control group compared with the normal control $(P<0.001)$ (Figure 1). Pretreatment with $\mathrm{Se}, \mathrm{Cr}(\mathrm{pic}) 3, \mathrm{Zn}$ and their combination significantly ameliorated the increase in MDA levels in rats compared with the ISO controls $(P<0.001)$. Pretreatment with Se significantly reduced the MDA cardiac levels compared with pretreatment with $\mathrm{Cr}($ pic $) 3 \quad(P<0.01)$ or $\mathrm{Zn}$ $(\mathrm{P}<0.001)$. The combination group showed significantly lower MDA levels compared

\section{The effect on reduced glutathione (GSH) levels}

$\mathrm{GSH}$, a non-enzymatic antioxidant, constitutes the first line of defense against free radicals and is a critical determinant of tissue susceptibility to oxidative damage. The administration of ISO led to a significant depletion of cardiac GSH levels in ISO-treated control group compared with normal controls $(P<0.05)$ (Figure 1). A significant elevation of GSH cardiac levels was observed upon pre-treatment with $\mathrm{Se}(P<0.001), \mathrm{Cr}($ pic $) 3$ $(P<0.05), \mathrm{Zn}(P<0.05)$ and their combination $(P<0.01)$. No significant changes were observed among the pre-treatment groups. Rats pretreated with Se displayed a non-significant increase in GSH levels compared with the $\mathrm{Cr}($ pic)3- and Znpretreated groups.

\begin{tabular}{|c|c|c|c|c|}
\hline \multirow[t]{2}{*}{ Treatment } & \multicolumn{2}{|c|}{ Body weight (g) } & \multirow{2}{*}{$\begin{array}{l}\text { Heart weight } \\
\text { (g) }\end{array}$} & \multirow{2}{*}{$\begin{array}{l}\text { Heart/body weight } \\
\text { ratio }\end{array}$} \\
\hline & Initial & Final & & \\
\hline Normal Control & $162.25^{\mathrm{a}} \pm 13.77$ & $231.75^{\mathrm{a}} \pm 10.6$ & $0.91^{\mathrm{a}} \pm 0.02$ & $0.40^{\mathrm{a}} \pm 0.01$ \\
\hline ISO control & $233.10^{b} \pm 6.20$ & $208.86^{\mathrm{b}} \pm 10.31$ & $1.05^{\mathrm{b}} \pm 0.05$ & $0.51^{\mathrm{b}} \pm 0.02$ \\
\hline $\mathrm{Se}+\mathrm{ISO}$ & $177.20^{\mathrm{a}} \pm 3.48$ & $230.56^{a} \pm 9.55$ & $0.93^{\mathrm{a}} \pm 0.04$ & $0.40^{\mathrm{a}} \pm 0.01$ \\
\hline $\mathrm{Cr}($ pic) $3+\mathrm{ISO}$ & $207.9^{\mathrm{a}} \pm 7.10$ & $226.22^{\mathrm{a}} \pm 7.76$ & $0.98^{\mathrm{a}} \pm 0.03$ & $0.43^{\mathrm{a}, \mathrm{c}} \pm 0.01$ \\
\hline Zn + ISO & $180.70^{\mathrm{a}} \pm 3.92$ & $212.11^{\mathrm{b}} \pm 5.40$ & $0.95^{\mathrm{a}} \pm 0.05$ & $0.45^{\mathrm{c}} \pm 0.02$ \\
\hline $\mathrm{Se}+\mathrm{Cr}($ pic $) 3+\mathrm{Zn}+\mathrm{ISO}$ & $227.5^{\mathrm{b}} \pm 2.5$ & $236.3^{\mathrm{a}} \pm 6.7$ & $1.01^{\mathrm{a}} \pm 0.03$ & $0.43^{\mathrm{a}, \mathrm{c}} \pm 0.01$ \\
\hline $\begin{array}{l}\text { Data are expressed as the } \\
\text { Tukey Krammer post hoc } \\
\text { The same characters signif }\end{array}$ & $\begin{array}{l} \pm \text { SEM. Group } \\
\text { ifferent characte } \\
\text { ignificant differe }\end{array}$ & $\begin{array}{l}\text { arisons were pe } \\
\text { icate a significa } \\
\text { etween values. }\end{array}$ & $\begin{array}{l}\text { using one-wa } \\
\text { nce between }\end{array}$ & $\begin{array}{l}\text { VA followed by the } \\
\text { in the same column; }\end{array}$ \\
\hline
\end{tabular}


Table 3. Effect of selenium (Se), chromium picolinate $\left[\mathrm{Cr}(\mathrm{pic})_{3}\right]$, zinc $(\mathrm{Zn})$ and their combination on the serum levels of cardiac troponin I and the activities of cardiac marker enzymes in ISO-induced MI in rats.

\begin{tabular}{|c|c|c|c|c|c|}
\hline Group & $\begin{array}{c}\text { cTnI } \\
(\mathrm{pg} / \mathrm{ml})\end{array}$ & $\begin{array}{c}\text { CK } \\
(\mathrm{U} / \mathrm{L})\end{array}$ & $\begin{array}{c}\text { CK-MB } \\
(\mathbf{U} / \mathbf{L})\end{array}$ & $\begin{array}{c}\text { AST } \\
(\mathbf{U} / \mathbf{L})\end{array}$ & $\begin{array}{l}\text { LDH } \\
(\mathrm{U} / \mathrm{L})\end{array}$ \\
\hline Normal Control & $11.95^{\mathrm{a}} \pm 0.44$ & $1903^{\mathrm{a}} \pm 133.8$ & $227.7^{\mathrm{a}} \pm 4.2$ & $133.8^{\mathrm{a}} \pm 2.87$ & $856.5^{\mathrm{a}} \pm 44.13$ \\
\hline ISO control & $18.6^{\mathrm{b}} \pm 0.6$ & $3682^{b} \pm 176$ & $410.6^{b} \pm 14.27$ & $263.5^{\mathrm{b}} \pm 15.1$ & $2043^{b} \pm 135$ \\
\hline $\mathrm{Se}+\mathrm{ISO}$ & $11.45^{\mathrm{a}, \mathrm{c}} \pm 0.4$ & $1384^{\mathrm{a}, \mathrm{c}} \pm 165.0$ & $191.3^{\mathrm{a}, \mathrm{c}} \pm 11.8$ & $158.1^{\mathrm{a}, \mathrm{c}} \pm 15.12$ & $665.3^{\mathrm{a}, \mathrm{c}} \pm 67.81$ \\
\hline $\mathrm{Cr}($ pic $) 3+\mathrm{ISO}$ & $11.9^{\mathrm{a}, \mathrm{c}} \pm 0.43$ & $1870^{\mathrm{a}, \mathrm{c}, \mathrm{d}} \pm 160.4$ & $226.5^{\mathrm{a}, \mathrm{c}, \mathrm{d}} \pm 7.3$ & $179.8^{\mathrm{a}, \mathrm{c}, \mathrm{d}} \pm 10.88$ & $1009^{\mathrm{a}, \mathrm{c}, \mathrm{d}} \pm 45.85$ \\
\hline $\mathbf{Z n}+\mathbf{I S O}$ & $14.1^{\mathrm{d}} \pm 0.53$ & $2089^{\mathrm{a}, \mathrm{d}} \pm 180.0$ & $243.1^{\mathrm{a}, \mathrm{d}} \pm 8.8$ & $224.5^{\mathrm{b}, \mathrm{d}} \pm 21.77$ & $1182^{\mathrm{a}, \mathrm{d}} \pm 64.5$ \\
\hline $\mathrm{Se}+\mathrm{Cr}(\mathrm{pic}) 3+\mathrm{Zn}+\mathrm{ISO}$ & $13.1^{\mathrm{a}, \mathrm{c}, \mathrm{d}} \pm 0.47$ & $1647^{\mathrm{a}, \mathrm{c}, \mathrm{d}} \pm 131.5$ & $209.3^{\mathrm{a}, \mathrm{c}, \mathrm{d}} \pm 8.4$ & $187.2^{\mathrm{a}, \mathrm{c}, \mathrm{d}} \pm 16.33$ & $1183^{\mathrm{a}, \mathrm{d}} \pm 92.5$ \\
\hline
\end{tabular}

Data are expressed as the means \pm SEM. Group comparisons were performed using one-way ANOVA followed by a Tukey Krammer post hoc test. Different characters indicate a significant difference between groups in the same column. All insignificantly different values are marked with the same character.

\section{The effect on enzymatic antioxidant activity}

Compared with normal control, the activities of CAT, SOD and GPx in myocardial tissues were significantly reduced in the ISO control group $(P<0.001)$; (Figure 2A-2C )however, these reduced activities were alleviated by pretreatment with Se, $\mathrm{Cr}$ (pic)3, $\mathrm{Zn}$ and their combination $(P<0.001)$. The $\mathrm{Se}, \mathrm{Cr}$ (pic) 3 and the combination groups showed higher CAT levels compared with the $\mathrm{Zn}$ supplemented rats $(P<0.001, \quad P<0.05, \quad P<0.01$, respectively). The Zn-pretreated group displayed higher SOD activity compared with Se or $\mathrm{Cr}$ (pic)3pretreated rats, but the difference was not significant. Cardiac GPx activities were significantly higher in the Se-pretreated group compared with the combination group $(P<0.05)$, while non-significant increase was observed in comparison with the $\mathrm{Zn}$ - or $\mathrm{Cr}($ pic)3-pretreated rats.

\section{Effect of $\mathrm{Se}, \mathrm{Cr}(\text { pic })_{3}, \mathrm{Zn}$ and their combination on cardiac levels of TNF- $\alpha$}

As revealed in Figure 3, the cardiac levels of TNF- $\alpha$ increased significantly in ISO-treated control rats compared with normal controls $(40.75 \pm 1.3$ vs. $22.15 \pm 0.27 \mathrm{pg} / \mathrm{g}$ tissue, $P<0.001)$. Such an elevation was significantly reversed by pretreatment with $\mathrm{Se}(25.32 \pm 1.65$ vs. $40.75 \pm 1.3 \mathrm{pg} / \mathrm{g}$ tissue, $P<0.001)$ and to lesser extent with $\mathrm{Cr}($ pic $) 3$
(32.2 \pm 1.77 vs. $40.75 \pm 1.3 \mathrm{pg} / \mathrm{g}$ tissue, $P<0.01), \mathrm{Zn}$ ( $31.83 \pm 1.19$ vs. $40.75 \pm 1.3 \mathrm{pg} / \mathrm{g}$ tissue, $P<0.01)$ and the combination treatment $(30.1 \pm 2.09$ vs. $40.75 \pm 1.3$ $\mathrm{pg} / \mathrm{g}$ tissue, $P<0.01)$ compared with the ISO controls. Rats pretreated with Se exhibited a significantly decreased TNF- $\alpha$ cardiac levels compared with those pretreated with $\mathrm{Zn}$ or $\mathrm{Cr}($ pic $) 3$ $(P<0.05)$.

Effect of Se, $\mathrm{Cr}$ (pic), $\mathrm{Zn}$ and their combination on cardiac levels of VEGF and serum levels of nitrite (index of NO) in ISO-induced MI in rats ( As shown in Figure 4, cardiac levels of VEGF were reduced dramatically in ISO control rats compared with the normal control group $(54 \pm 2.38$ vs. $127.2 \pm 12.33 \mathrm{pg} / \mathrm{g}$ tissue, $P<0.001$ ) (Figure 4). Pretreatment with Se, $\mathrm{Zn}$ and the combination of $\mathrm{Se}+\mathrm{Cr}($ pic $) 3+\mathrm{Zn}$ significantly attenuated this reduction, leading to normalization of VEGF compared with ISO control rats (Se: $128.2 \pm 13.13$ vs. $54 \pm 2.38, P<0.001 ; Z n: 129.8 \pm 23.8$ vs. $54 \pm 2.38$, $P<0.01$; combination: $106.3 \pm 6.5$ vs. $54 \pm 2.38$, $P<0.05)$. 
A

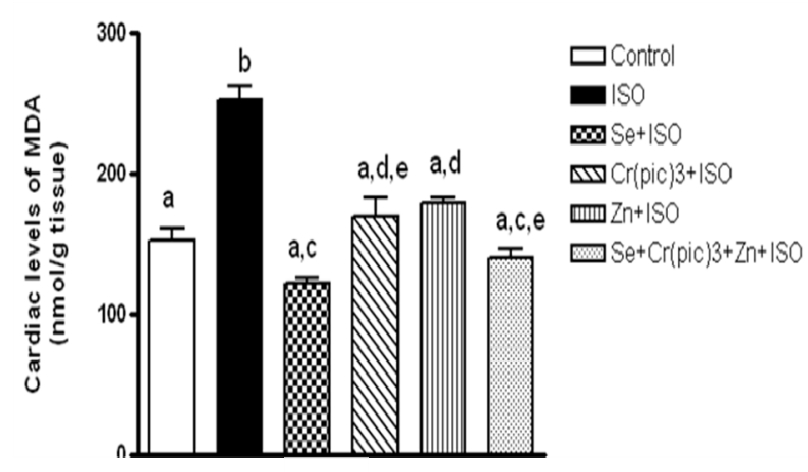

B

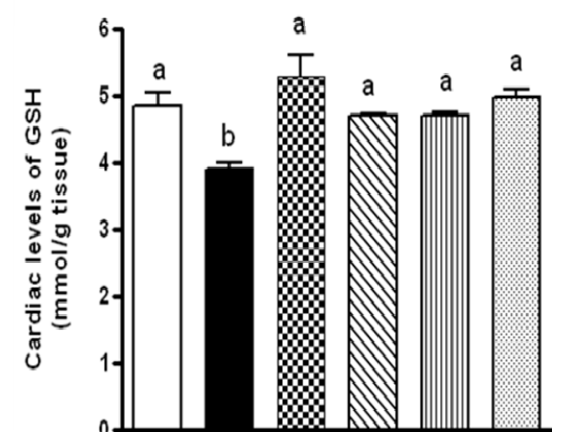

Figure 1. Effect of selenium (Se), chromium picolinate $\left[\mathrm{Cr}(\mathrm{pic})_{3}\right]$, zinc $(\mathrm{Zn})$ and their combination on the cardiac levels of (A): malondialdehyde (MDA, an index of lipid peroxidation) and (B): reduced glutathione (GSH, a nonenzymatic antioxidant) in ISO-induced MI in rats. Data are expressed as the means \pm SEM. Group comparisons were performed using one-way ANOVA followed by a Tukey Krammer post hoc test. Different characters indicate significant differences between groups. All insignificantly different values are marked with the same character.

In contrast, pretreatment with $\mathrm{Cr}$ (pic)3 alone did not produce any change in cardiac VEGF levels compared with ISO controls (48.36 $\pm 0.83 \mathrm{pg} / \mathrm{g}$ tissue vs. 54 \pm 2.38 ). Myocardial levels of VEGF were significantly higher in rats pretreated with $\mathrm{Se}$ or $\mathrm{Zn}$ alone $(P<0.001)$ and also in the combination group $(P<0.01)$ compared with the levels in $\mathrm{Cr}$ (pic)3-pretreated rats. There is growing evidence that VEGF increases the production of $\mathrm{NO}$, and thus the activity of the two factors may be associated. In contrast to this finding, the data in Figure 4 indicated that the serum levels of nitrite (an index for NO production) were significantly elevated in the ISO-treated control group compared with the normal control rats $(82.6 \pm 7.7$ vs.
$40.9 \pm 2.03, P<0.001)$. These elevated levels were significantly alleviated by pretreatment with $\mathrm{Se}$ $(42.07 \pm 2.7 \mu \mathrm{mol} / \mathrm{L}$ vs. $82.6 \pm 7.7, \quad P<0.001)$, $\mathrm{Cr}($ pic) $3 \quad(52.73 \pm 2.5$ vs. $82.6 \pm 7.7, P<0.01), \mathrm{Zn}$ $(60.38 \pm 3.0$ vs. $82.6 \pm 7.7, P<0.05)$ or their combination ( $42.72 \pm 2.6$ vs. $82.6 \pm 7.7, P<0.001)$.
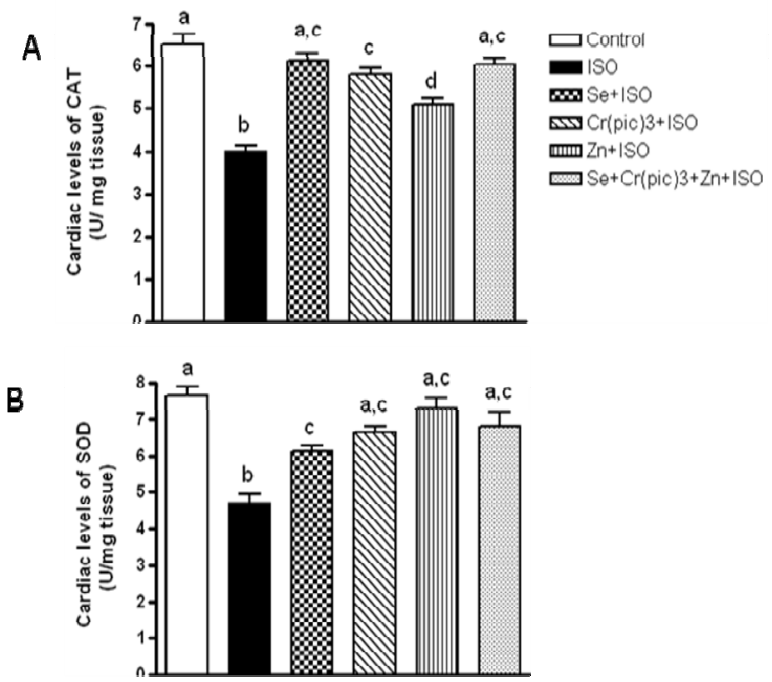

C

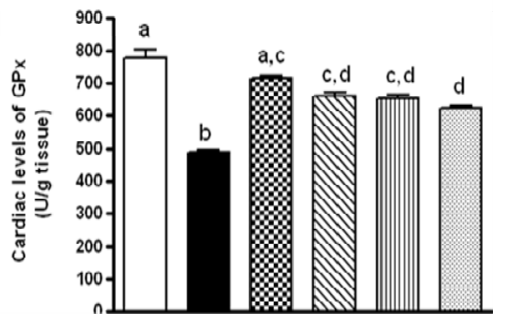

Figure 2. Effect of selenium (Se), chromium picolinate $\left[\mathrm{Cr}(\mathrm{pic})_{3}\right]$, zinc $(\mathrm{Zn})$ and their combination on the cardiac levels of the antioxidant enzymes (A): catalase (CAT), (B): superoxide dismutase (SOD) and (C): glutathione peroxidase (GPx) in ISO-induced MI in rats. Data are expressed as the means \pm SEM. Group comparisons were performed using one-way ANOVA followed by a Tukey Krammer post hoc test. Different characters indicate significant differences between groups. All insignificantly different values are marked with the same character.

The Se- and combination-pretreated rats exhibited significant lower serum nitrite levels compared with the $\mathrm{Zn}$-pretreated group $(P<0.05)$. The inverse relationship between VEGF and nitrite was observed in the present study and indicated statistically as shown in Figure 5 by the significant negative correlation between cardiac levels of 
VEGF and serum nitrite levels in ISO control rats $(\mathrm{r}=-0.96, P<0.001)$, Se-pretreated rats $(\mathrm{r}=-0.81$, $P<0.05)$ and $\mathrm{Zn}$-pretreated rats $(\mathrm{r}=-0.78, P<0.05)$, whereas the correlation was not significant in the combination-pretreated group $(\mathrm{r}=-0.74, P=0.09)$.

\section{Effect of Se, $\mathrm{Cr}(\mathrm{pic})_{3}, \mathrm{Zn}$ and their combination on serum lipid profile}

As shown in Figure 6, a highly significant rise in the serum levels of TC, TG and LDL-C and a marked reduction in HDL-C were observed in ISOtreated control infarcted rats compared with the normal control rats $(P<0.001)$. Pretreatment with Se did not significantly improve the levels of TC or TG compared with the ISO control group; however,

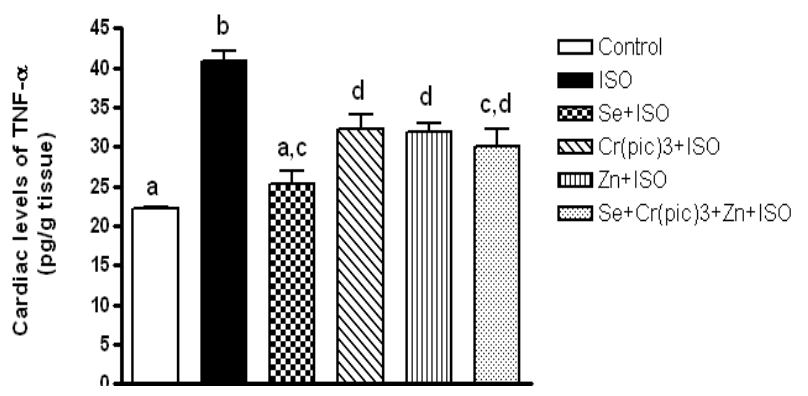

Figure 3. Effect of selenium (Se), chromium picolinate $\left[\mathrm{Cr}(\mathrm{pic})_{3}\right]$, zinc $(\mathrm{Zn})$ and their combination on cardiac levels of tumor necrosis factor- $\alpha$ (TNF- $\alpha$ ) in ISOinduced MI in rats. Data are expressed as the means \pm SEM. Group comparisons were performed using oneway ANOVA followed by a Tukey Krammer post hoc test. Different characters indicate significant differences between groups. All insignificantly different values are marked with the same character.

the Se pretreatment significantly reduced the serum levels of LDL-C $(P<0.01)$ while increasing the HDL-C $(P<0.05)$ levels in comparison with the ISO control group. In contrast to Se, pretreatment with $\mathrm{Cr}$ (pic)3 led to a significant improvement in all lipid profile parameters with a significant reduction in the serum levels of TC $(P<0.01)$, TG $(P<0.05)$ and LDL-C $(P<0.001)$ together with a significant increase in HDL-C $(P<0.001)$ compared with the ISO control group. Pretreatment with $\mathrm{Zn}$ significantly decreased the levels of TC $(P<0.01)$ and LDL-C $(P<0.001)$ and increased the HDL-C $(P<0.01)$ in comparison with the ISO controls, whereas a non-significant decrease was observed concerning TG serum levels. Regarding the combination group, the combination treatment did not significantly alter the serum levels of TC or TG, whereas the treatment significantly increased HDLC $(P<0.05)$ and markedly decreased LDL-C $(P<0.001)$ serum levels compared with the ISO control group. In comparison with each other, the $\mathrm{Cr}$ (pic) 3 and $\mathrm{Zn}$ treatments showed significantly reduced serum levels of LDL-C in treated rats compared with both the Se- and the combinationpretreated groups $(P<0.05)$.

\section{Histological examination}

Histological examination of cardiac muscle tissue stained with H\&E (Figure 7) revealed massive muscle cells degeneration and excessive inflammatory cellular infiltration in the heart of ISO control rats. Pretreatment with $\mathrm{Se}$ led to a prominent improvement of muscle cells with minimal cytoplasmic changes and very little cellular infiltration and most of cardiac cells appeared healthy. Pretreatment with $\mathrm{Cr}($ pic $) 3$ resulted in a moderate improvement of cellular degeneration with little inflammatory cellular infiltration, whereas the heart tissue of Zn-pretreated rats displayed little cellular degeneration and cellular infiltration remained. The cardiac muscle tissue of combination-pretreated rats showed moderate improvement, as indicated by little cellular infiltration and cardiac cell degeneration.

\section{Immunohistochemistry of the p47 phox NADPH oxidase subunit}

The myocardial tissue from normal control rats was characterized by weak $\mathrm{p} 47$ phox immunostaining of muscle fibers (Figure 8-A). The heart muscles of ISO control rats showed intensive immunostaining of p47 phox (Figure 8-B). Rats pretreated with Se showed a marked decrease in the immune reaction in myocardial tissue (Figure 8-C). The hearts of the rats pretreated with $\mathrm{Cr}($ pic $) 3$ or a combination revealed a moderate decrease in p47 phox immunostaining (Figure $8 \mathrm{D}$ and $\mathrm{F}$ ), while hearts of rats that received $\mathrm{Zn}$ exhibited the least improvement compared with the other pretreatment groups (Figure 8-E).

\section{DISCUSSION}

In the present study, ISO-induced MI rat model was used to assess the cardioprotective effects of Se, $\mathrm{Cr}(\mathrm{pic}) 3, \mathrm{Zn}$ and their combination on oxidative stress, inflammatory response and dyslipidemia in MI. In addition, the possible angiogenic mechanisms operating via increasing cardiac VEGF and serum NO were also investigated. 
A

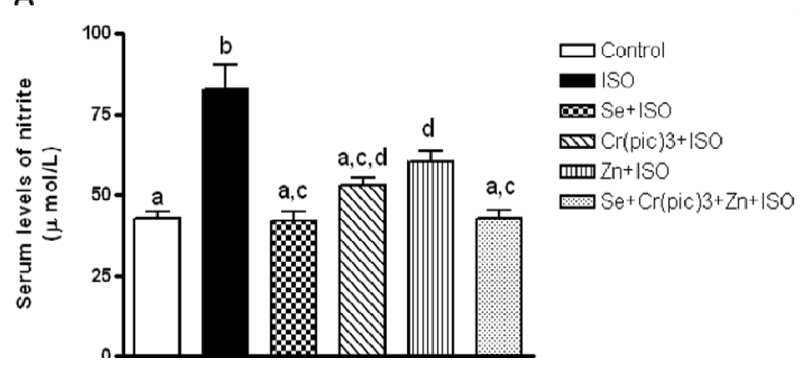

B

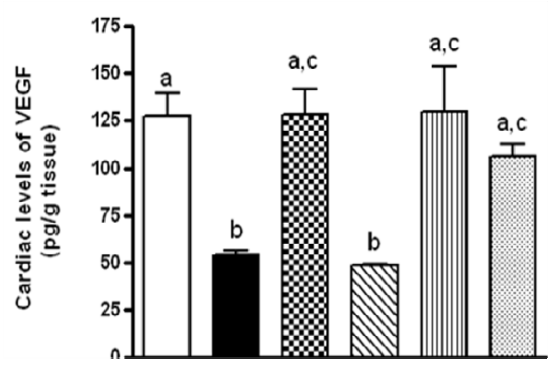

Figure 4. Effect of selenium (Se), chromium picolinate $\left[\mathrm{Cr}(\mathrm{pic})_{3}\right]$, zinc $(\mathrm{Zn})$ and their combination on (a): Serum levels of nitrite (index of NO) and (b): cardiac levels of vascular endothelial growth factor (VEGF) in ISOinduced MI; Data are expressed as the means \pm SEM. Group comparisons were performed using one-way ANOVA followed by a Tukey Krammer post hoc test.means. Different characters indicate significant differences. No significantly different when marked with the same character.

In consistent with previous reports $(14,18,19)$ our results (Table 1) revealed significantly decreased serum levels of $\mathrm{Se}, \mathrm{Cr}$ and $\mathrm{Zn}$ in ISO control group. This elements dyshemostasis plays a critical role in the pathogenesis of MI (20) which strongly suggests the beneficial effects of trace elements supplementation on the outcome of MI. Supplementation with $\mathrm{Se}, \mathrm{Cr}$ and $\mathrm{Zn}$ significantly restored the normal levels of the corresponding element. In addition, the extensive heart weight increase and the increase in the heart to body weight ratio observed in ISO control rats is suggestive of cardiac hypertrophy which may be due to ventricular stiffness, increased water content, edematous intermuscular space and extensive necrosis of cardiac muscle followed by invasion of the damaged tissue by inflammatory cells (54). Pretreatment with $\mathrm{Se}, \mathrm{Cr}$ (pic)3, $\mathrm{Zn}$ and their combination significantly decreased the heart to body weight ratio suggesting that these metals could effectively suppress the stimulus for hypertrophy. The reduction of heart to body weight ratio was prominent in Se-pretreated rats (Table 2) highlighting the possible superior role of Se alone in restoring the normal ratio.

As expected and reported before $(1,2,40)$, marked elevations in the serum levels of AST, $\mathrm{LDH}, \mathrm{CK}, \mathrm{CK}-\mathrm{MB}$ and cTnI were observed in ISO control rats, reflecting myocardial cell damage, cell membrane permeability or rupture, which results in the leakage of these markers into the serum (1). This elevation was significantly lowered by pretreatment with $\mathrm{Se}, \mathrm{Cr}(\mathrm{pic}) 3, \mathrm{Zn}$ and their combination reflecting their potential role in membrane stabilization and in reducing the extent of myocardial damage. Notably, results of Table 3 revealed that $\mathrm{Zn}$ pretreatment had less prominent improvement effects, suggesting that $\mathrm{Se}$ and, to a lesser extent, $\mathrm{Cr}(\mathrm{pic}) 3$ may be more effective as cardioprotective elements.

The loss of myocardial membrane integrity has been related to the generation of highly cytotoxic free radicals (40), which may be derived in this model of MI from: i) the reduced serum levels of $\mathrm{Se}, \mathrm{Cr}$ and $\mathrm{Zn}$ which leads to oxidative stress with the production of ROS (20); ii) the excess metabolites produced by a supramaximal dose of ISO, which led to increased production of free radicals such as $\mathrm{O}_{2}{ }^{--}$anions, $\mathrm{H}_{2} \mathrm{O}_{2}$ and hydroxyl radicals (1). The generation of $\mathrm{O}_{2}{ }^{--}$anions was indicated in our study by the significantly increased immunostaining of $\mathrm{p} 47 \mathrm{phox}$ in the cardiac tissue of ISO control group reflecting the activation of NADPH oxidase; the major source of $\mathrm{O}_{2}{ }^{--}$anions in the heart. The generated $\mathrm{O}_{2}{ }^{--}$anions are potential oxidizers of membrane lipids, with significantly increased levels of MDA end products, and are therefore postulated to induce MI through damage to cellular membranes and the development of inflammatory response (20). It is postulated that the myocardial antioxidants were consumed during scavenging of these high levels of free radicals explaining the reduced levels of GSH and the activities of SOD, CAT and GPx in ISO control rats.

The high levels of myocardial MDA and the reduced concentration and activities of GSH, SOD, GPx and CAT were significantly attenuated by oral pretreatment with $\mathrm{Se}, \mathrm{Cr}(\mathrm{pic}) 3, \mathrm{Zn}$ and their combination indicating the radical scavenging and antioxidant activities of these trace metals. 

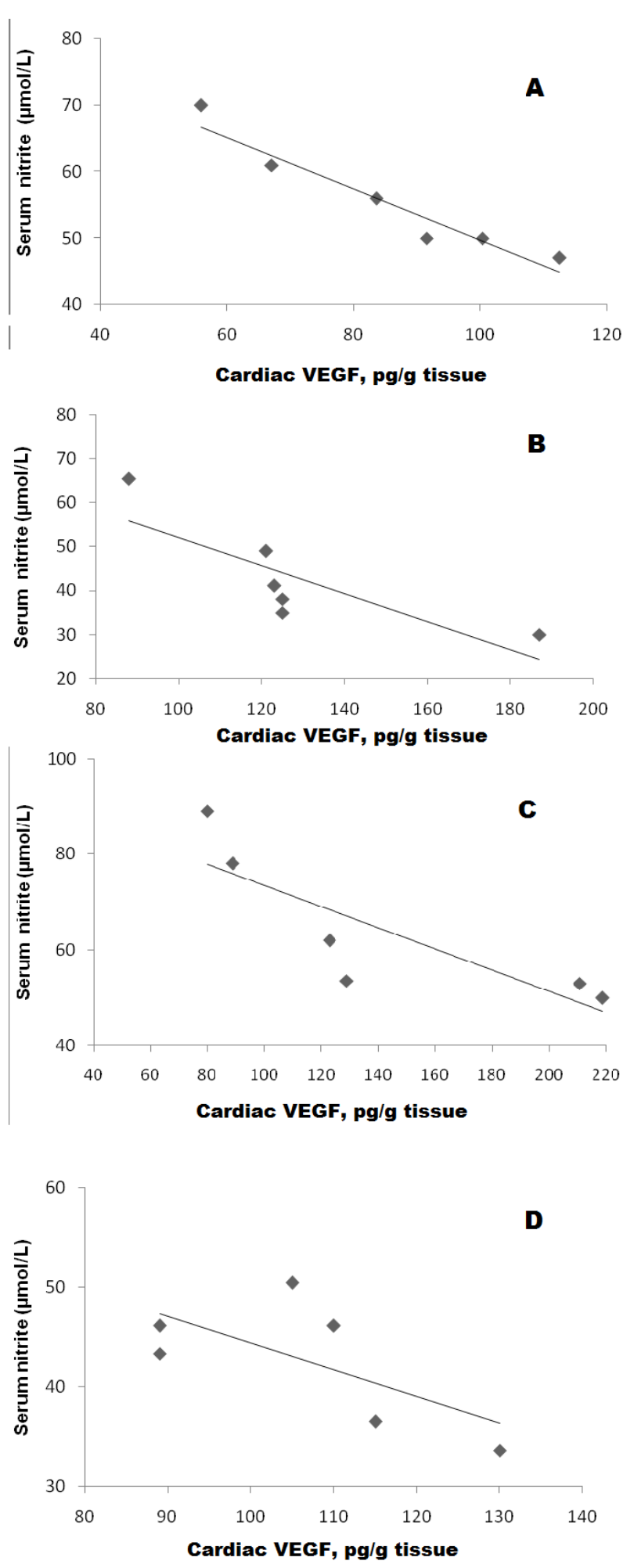

Figure 5. Negative correlation between cardiac levels of VEGF (pg/g tissue) and serum nitrite levels $(\mu \mathrm{mol} / \mathrm{L})$ in (A): ISO control rats $(\mathrm{r}=-0.96, \mathrm{P}<0.001)$; (B): Rats pretreated with $\mathrm{Se}(\mathrm{r}=-0.81, \mathrm{P}<0.05),(\mathrm{C})$ : $\mathrm{Zn}-$ pretreated rats $(\mathrm{r}=-0.78, \mathrm{P}<0.05)$ and $(\mathrm{D})$ : the combination-pretreated group $(\mathrm{r}=-0.74, \mathrm{P}=0.09)$.
One proposed mechanism of such antioxidant potential is the reduced activation of NADPH oxidase enzyme which evident in our study by the restoration of the normal concentration of $\mathrm{p} 47 \mathrm{phox}$ in cardiac tissue, and as a result the production of $\mathrm{O} 2^{-}$radicals could be attenuated. As observed in Figure 8, it is noted that $\mathrm{Se}, \mathrm{Cr}(\mathrm{pic}) 3$ and the combination showed less p47phox immunoreactivity, and so lower NADPH oxidase activation than $\mathrm{Zn}$. Antioxidant action of $\mathrm{Zn}$ could be largely related to the maintenance of tissue concentrations of metallothionein, a powerful freeradical scavenger $(39,55)$, and the contribution to the structure of the antioxidant enzyme SOD (55), whose activity was restored to normal levels by pretreatment with $\mathrm{Zn}$ in our study. Recent studies have demonstrated that high-dietary selenium is associated with lower cardiac oxidative stress, increased GPx expression and reduced heart failure after reperfusion infarction (56) and in ageing spontaneously hypertensive rats (57). $\mathrm{Cr}$ (pic) 3 has been demonstrated to attenuate hyperglycemiainduced oxidative stress in diabetic rats (30) and to exert beneficial effects on several markers of oxidative stress and inflammation in obese Zucker rats (31). Our data revealed that $\mathrm{Se}$ is superior to $\mathrm{Cr}(\mathrm{pic}) 3$ and $\mathrm{Zn}$ in alleviating oxidative cardiac damage in this model of MI. Se functions primarily through the selenoenzyme; GPx, the activities of which are responsible for the recognition of Se as an important dietary antioxidant (58). GPx catalyzes the reduction of $\mathrm{H}_{2} \mathrm{O}_{2}$ and organic hydroperoxides to harmless products. This function helps to maintain membrane integrity and to reduce further oxidative damage to biomolecules such as lipids and lipoproteins with the associated increased risk of conditions such as atherosclerosis (59). This finding explains the significantly attenuated MDA levels produced by Se compared with $\mathrm{Cr}($ pic $) 3$ and $\mathrm{Zn}$ in our study.

In MI, the burst of ROS production from cardiomyocytes can exacerbate local inflammatory response, as was evident in our study by the significantly elevated cardiac levels of TNF- $\alpha$ in the ISO control group. Moreover, histological examination of cardiac tissues revealed a massive interstitial edema and infiltration of inflammatory cells in ISO control rats, indicating an acute inflammatory response in the myocardium. Murray et al. (60) confirmed that $\beta$-adrenergic stimulation is a stimulus for local myocardial expression of inflammatory cytokines in experimental rats. 


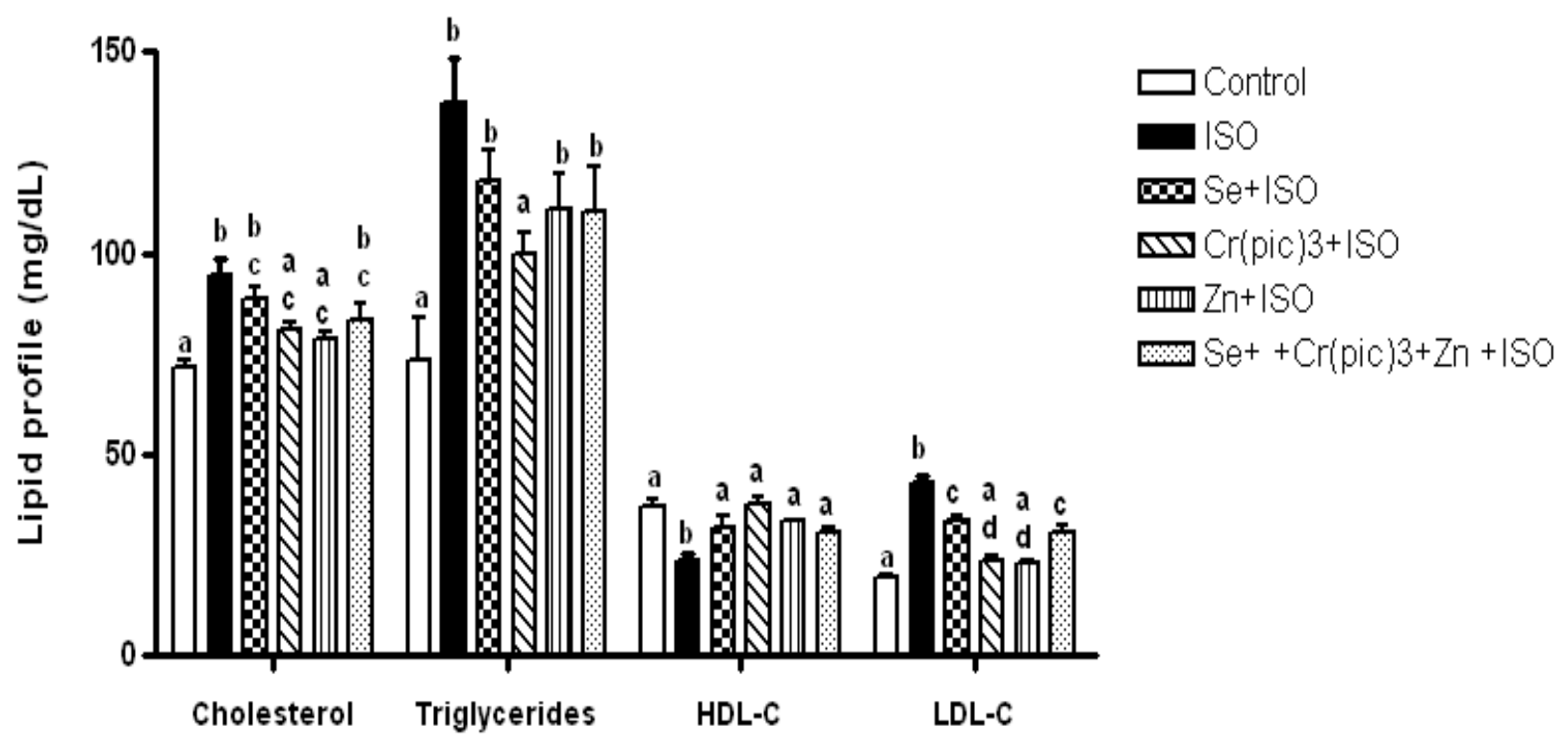

Figure 6. Effect of selenium (Se), chromium picolinate $\left[\mathrm{Cr}(\mathrm{pic})_{3}\right]$, zinc $(\mathrm{Zn})$ and their combination on serum levels of total cholesterol, triglycerides, HDL-C and LDL-C (mean \pm SEM) in ISO-induced MI in rats. Data are expressed as the means \pm SEM. Group comparisons were performed using one-way ANOVA followed by a Tukey Krammer as post hoc test. Different characters indicate significant differences between groups. All insignificantly different values are marked with the same character.
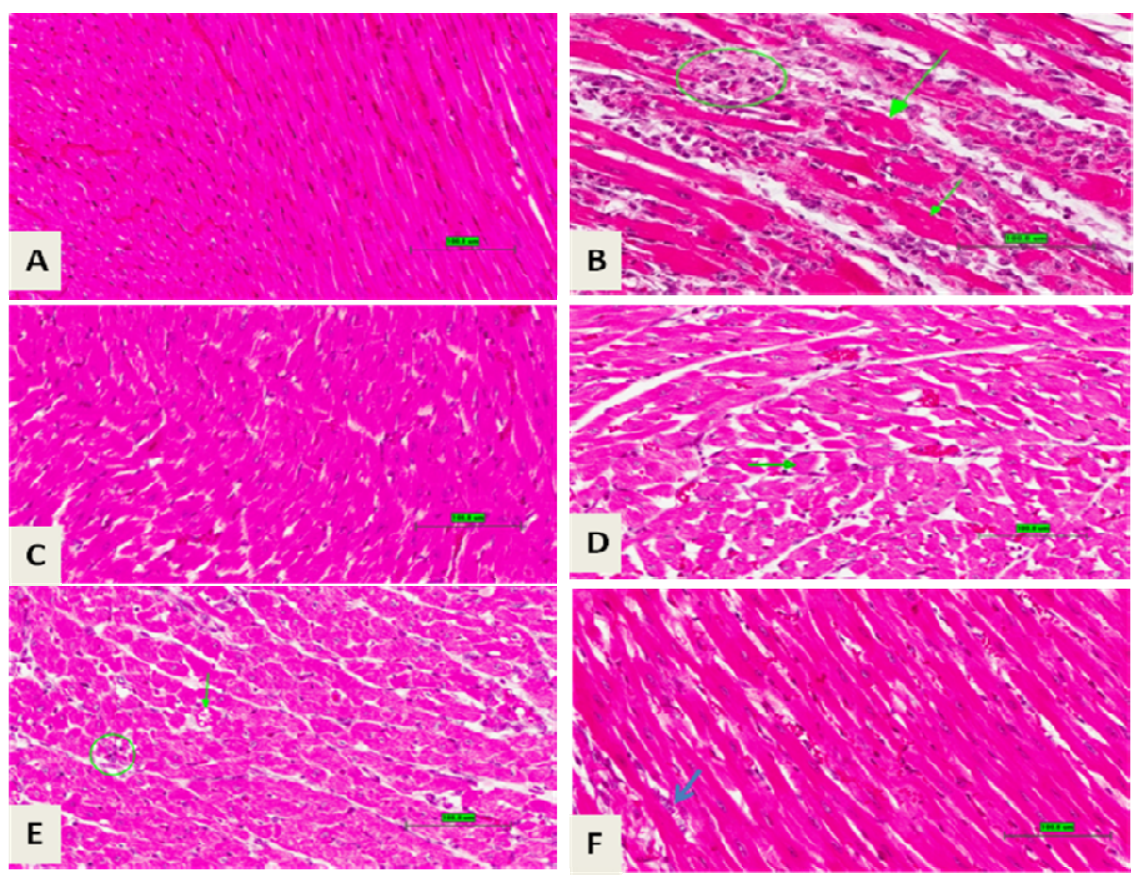

Figure 7. Light micrographs of cardiac muscle tissue stained with H\&E. (A) Normal control with normal muscle fibers and normal inter-muscular tissue and vasculature; (B) Representative heart of an ISO control rat that displays massive muscle cells degeneration (arrows), excessive inflammatory cellular infiltration (circle) and widening of inter-cellular connective tissue; (C) Representative cardiac muscle of Se-pretreated rats, showing prominent improvement of muscle cells with very minimum and few cytoplasmic changes in addition to little cellular infiltration; (D) Representative cardiac muscle tissue of $\mathrm{Cr}(\mathrm{pic}) 3$-pretreated rats showing medium improvement of cellular degeneration (arrow) with little inflammatory cellular infiltration; (E) Representative heart tissue of Zn-pretreated rats, showing little cellular degeneration (arrow) and still cellular infiltration (circle); (F) Cardiac muscle tissue of a combination-pretreated rats showing moderate improvement as indicated by little cellular infiltration (arrow) and little cardiac cell degeneration (Scale bar $100.8 \mu \mathrm{m}$ ) 

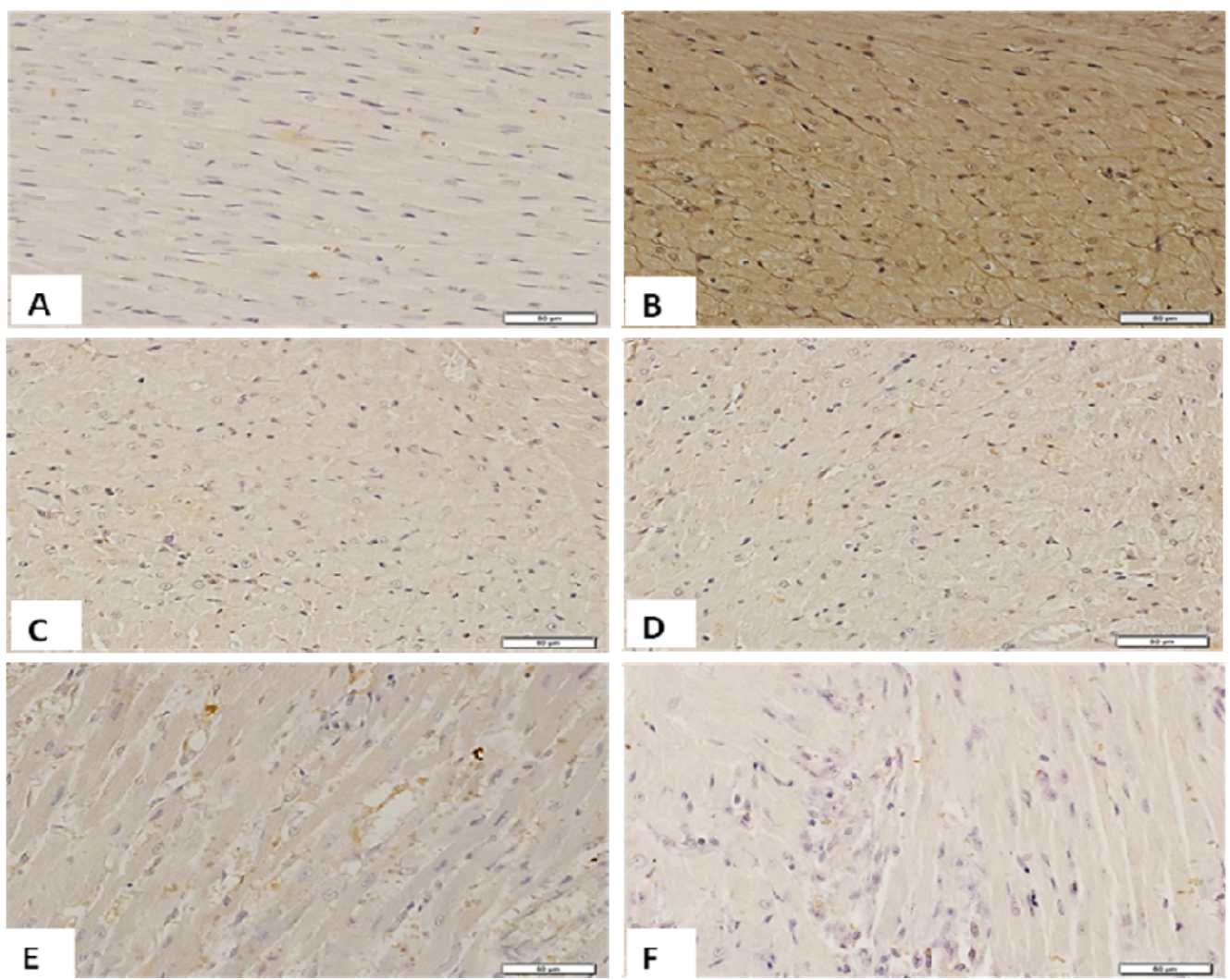

Figure 8. Light photomicrographs of heart sections immunostained with $\mathrm{p} 47$ phox antibody (Scale bar $100 \mu \mathrm{m}$ ). (A) Heart of normal control rat with weak immune reaction in myocardial cells; (B) Heart of ISO control rat showing severe intense immune reactivity of all myocardial cells; (C) Heart of Se-pretreated rat showing marked decrease of immune reactivity of both intensity and distribution; (D) Heart of $\mathrm{Cr}$ (pic)3-pretreated rats showing moderate improvement and marked decrease of immune reaction; (E) Representative heart of rats pretreated with $\mathrm{Zn}$ showing improvement, but less prominent compared with the $\mathrm{Se}$ or $\mathrm{Cr}$ (pic)3-treated rats; (F) Heart of rat pretreated with a combination of $\mathrm{Se}, \mathrm{Cr}(\mathrm{pic}) 3$ and $\mathrm{Zn}$ showing a marked decrease of immune reactivity of both intensity and distribution.

Chandrasekar et al. (61) also demonstrated that an abnormal dose of ISO can induce the activation of nuclear factor kappa B (NF-kB), suggesting that the activation of $\beta$-adrenoceptors contributes to a proinflammatory state of the cardiovascular system. In the present study, reduced levels of cardiac TNF- $\alpha$ together with minimal inflammatory cellular infiltration, were observed following pretreatment with $\mathrm{Se}, \mathrm{Cr}$ (pic)3, $\mathrm{Zn}$ and their combination with a particular significantly lower TNF- $\alpha$ and histological improvement observed with $\mathrm{Se}$ pretreatment. Because ROS is a key activator of NF-kB; a major transcription factor that controls the expression of inflammatory genes (32), antioxidants can be efficient anti-inflammatory agents via inhibition of NF-kB activation. Panicker et al. (14) reported that the interaction of Se with NF-kB protein may be one mechanism for the antiinflammatory and cardioprotective effects of $\mathrm{Se}$ against MI. Similarly, $\mathrm{Cr}$ (pic)3 has been reported to decrease the levels of TNF- $\alpha$ by reducing the levels of ROS and subsequent NF-kB inhibition (32-34). Recently, Panicker et al. (62) found that rats, when pretreated with selenium before the induction of MI, is efficient in blocking the leukotriene biosynthetic pathway, through inhibiting the expression of both lipooxygenase and leukotriene A4 hydrolase, the two key enzymes in the synthesis of proinflammatory mediator leukotriene B4. Our results provide evidence that $\mathrm{Se}, \mathrm{Cr}$ (pic) 3 and $\mathrm{Zn}$ play an important role as anti-inflammatory agents in a rat model of MI, and that Se may be the most potent cardioprotective agent of those tested elements.

VEGF is known as a key mediator of ischemiadriven angiogenesis as it is the major stimulator of the growth of new blood vessels. However, in the present study, cardiac levels of VEGF were reduced significantly in the ISO control group indicating 
impaired angiogenesis. Previous reports have demonstrated that angiogenesis may be inadequate in post-MI hearts, as indicated by the severely reduced coronary conductance $(63,64)$. Therapeutic angiogenesis is therefore a promising therapy for ischemic diseases. The current study is the first to investigate the effect of $\mathrm{Se}, \mathrm{Cr}$ (pic) 3 or $\mathrm{Zn}$ on the cardiac levels of VEGF in experimentally induced $\mathrm{MI}$ in rats. Pretreatment with $\mathrm{Se}, \mathrm{Zn}$ and the combination, but not $\mathrm{Cr}$ (pic)3 significantly increased the cardiac levels of VEGF, which implies that these elements had angiogenic effects in hypoxic conditions. While Se exhibited angiogenic effects in our study and in diabetic states (65), previous data support an anti-angiogenic effect of Se in the chemoprevention of many types of cancer $(66,67)$ which imply that Se may act as anti-angiogenic or angiogenic depending on physiologic and metabolic conditions.

Previous studies have found that VEGF acts through receptors in the endothelium to increase the production of NO by nitric oxide synthase (NOS), and thus the activity of the two growth factors may be associated (9). In cardiovascular system, NO is produced by two isoforms of NOS, inducible (iNOS) and endothelial (eNOS). The iNOS-derived NO was reported to promote survival of ischemic tissue by stimulating angiogenesis elicited by VEGF (10). Recently, Zaitone and Abo-Gresha (40) demonstrated that the increase in ischemia-induced angiogenesis in experimentally-infarct hearts was mediated by increased expression of iNOS and VEGF in cardiac tissues. In contrast to previous findings, we found a strong negative correlation between the levels of VEGF and serum nitrite (an index of NO production) in ISO control group (Figure 5-A). Therefore the significant elevation of nitrite was associated with a significant decrease of VEGF in cardiac tissues. Indeed, there is a controversy regarding the role of $\mathrm{NO}$ in angiogenesis. In vitro studies reported that $\mathrm{NO}$ inhibited the migration of cultured endothelial cells; an important step in angiogenesis (68). Similarly, NO donors were reported to inhibit angiogenesis in a chick chorioallantoic membrane model (69). Collectively, present and previous data may suggest the adverse effect of NO on VEGF-induced angiogenesis in ISO-induced MI. In the present study, the significantly increased cardiac levels of VEGF induced by Se or $\mathrm{Zn}$ pretreatment are possibly via reducing the levels of serum nitrite. The significant negative correlation between cardiac VEGF and serum nitrite observed in the Se and $\mathrm{Zn}$-pretreated groups confirms this explanation (Figures 5B, 5C). Although $\mathrm{Cr}($ pic)3 significantly reduced the levels of serum nitrite, it failed to correct the VEGF levels reflecting that NO is not the sole factor regulating VEGF levels in infarcted heart.

Since iNOS is expressed in response to inflammatory cytokines (9), high levels of nitrite observed in the present study could be a consequence of inflammatory response. Because of its highly reactive nature, increased nitrite levels, especially associated with oxidative stress, is harmful and can be destructive to healthy tissue. That is because nitrite rapidly reacts with $\mathrm{O} 2{ }^{--}$anions to give rise to peroxynitrite, which can nitrosate thiols to modify key signaling molecules such as kinases and transcription factors (70). ISOinduced cardiotoxicity could be therefore explained by the formation of NO. In addition, inadequate Se is associated with an increase in reactive nitrogen species such as NO and peroxynitrite production (58), which have been linked to increased risks of cardiomyopathy. Therefore, Se-pretreatment, and also $\mathrm{Cr}$ (pic)3, $\mathrm{Zn}$ and the combination, significantly reduced serum nitrite levels which may be related to their antioxidant effects. Se was more effective in reducing nitrite levels confirming the potential antioxidant and cardioprotective power of Se compared to $\mathrm{Cr}$ and $\mathrm{Zn}$. Consistent with the current results, Se protects the immature rat hearts against ischemia/reperfusion injury by reducing serum nitrite levels (71). The inhibitory effect of Se supplementation on NO production has been investigated in different models $(23,71)$ and this inhibition can be useful in the treatment of inflammatory conditions. There have been only a few studies concerning the effect of $\mathrm{Cr}($ pic) 3 or $\mathrm{Zn}$ on NO production in pathologic conditions (72).

Altered lipid profile (increased TC, TG, VLDL and LDL and decreased levels of HDL) was extensively reported in ISO-induced MI $(2,11,54$, 73-75). In agreement with previous investigations, our results revealed significantly higher serum TC, TG and LDL levels, and lower HDL in ISO-control rats compared to normal control. Under severe ischemic conditions, the oxidation of carbohydrates and free fatty acids will cease; thus, circulating free fatty acids are increased in myocardial infarcted rats (11). The observed significantly increased TG levels in our study after MI may be due to the 
elevated flux of fatty acids and impaired removal of VLDL from the plasma (11). Only $\mathrm{Cr}$ (pic)3 significantly decreased serum TG levels in our study. Several studies have reported the beneficial effects of $\mathrm{Cr}$ (pic)3 supplementation in ameliorating hyperlipidemia and lowering the levels of blood free fatty acids (29-35). These effects improve the cardiac functions and decrease the extent of myocardial damage. TNF- $\alpha$ has been shown to increase plasma TG and concentrations of VLDL (76), as well as lipolysis in fat cells (77).These findings suggest that improvements in TG levels could be due to reduced TNF- $\alpha$ levels in $\mathrm{Cr}($ pic $) 3$ supplemented groups. Significantly reduced TC was observed by $\mathrm{Cr}($ pic) 3 and Zn, but not with Se. Our data reflect that $\mathrm{Cr}(\mathrm{pic}) 3$ alone followed by $\mathrm{Zn}$ alone possesses more prominent antihyperlipidemic effects compared with Se.

As shown in the current study, MI was associated with significantly increased serum levels of LDL-C, whereas HDL-C levels were significantly reduced. The increased serum levels of LDL-C in ISO control group could be attributed to ROS-mediated oxidation of LDL; ox-LDL is not recognized by the LDL receptors and is therefore increased in the blood (78). Oxidized LDL-C may induce endothelial damage and thus facilitate the atherogenic process (79). Being antioxidants, pretreatment with $\mathrm{Se}, \mathrm{Cr}($ pic)3, $\mathrm{Zn}$ and the combination significantly ameliorate the increase in LDL-C serum levels. Some investigators have speculated that GPx protects endothelial cells from the effects of oxidized LDL-C (79), which explains the anti-atherogenic effect of these elements via increasing GPx. The increased levels of serum HDL-C, observed by the pretreatment with the tested metals, facilitate the transport of cholesterol from peripheral tissues to the liver for catabolism and excretion from the body. Previous results suggest a link between low serum Se and $\mathrm{Cr}$ III deficiency to reduced HDL-C and thus high coronary risk. Our and previous data support the anti-atherogenic effect of $\mathrm{Cr}($ pic $) 3(29,34,35), \mathrm{Zn}$ (38) and Se (24). $\mathrm{Cr}$ (pic) 3 and $\mathrm{Zn}$ significantly reduced serum levels of LDL-C compared with both Se and combination, which may emphasize the superiority of $\mathrm{Cr}($ pic $) 3$ and $\mathrm{Zn}$ in ameliorating ISOinduced dyslipidemia.

Although the combination showed improvement in almost all parameters, the efficacy of the element combination was not superior to that of $\mathrm{Se}, \mathrm{Cr}(\mathrm{pic}) 3$ or $\mathrm{Zn}$ alone and no synergism or additive effects was observed. Based on the data of Table 1, an interaction between the tested metals, particularly $\mathrm{Cr}$ and Se, could be concluded. The significant decreases in Se concentrations in whole blood and plasma observed in tannery workers exposed to $\mathrm{Cr}$ compounds (80) may confirm this hypothesis. It has also been reported that $\mathrm{Cr}$ counteracts the inhibitory effect of $\mathrm{Se}$ on tumor development in a dose-dependent manner (81). Exposure to $\mathrm{Cr}$ also altered the levels of $\mathrm{Se}$ in the liver and kidneys of mice, indicating that $\mathrm{Cr}$ interacts with organ distribution of Se (81). Our results suggest the exclusion of concomitant administration of $\mathrm{Cr}$ and Se. Since Se was more effective as both antioxidant and angiogenic, while $\mathrm{Cr}$ was more effective in reducing lipids, we suggest daily individual administration of $\mathrm{Cr}$ and Se.

One of the limitations in the current study is the use of a combination of the three metals, instead of a combination of each two of them. $\mathrm{Zn}$ was effective in improving all parameters but less effective than Se as an antioxidant or as angiogenic, whereas it was more effective as antihyperlipidemic. In the present study, pretreatment of $\mathrm{Zn}$ significantly improved the serum levels of Se (Table 1) compared to ISOcontrol. Se supplementation also modulated, however non significantly, the levels of $\mathrm{Zn}$. Recently, supplementation of Se $(0.5 \mathrm{mg} / \mathrm{kg}$ as selenite) has been reported to modulate zinc levels in blood and tissues of diabetic rats fed zincdeficient diet (82) suggesting the beneficial role of Se in $\mathrm{Zn}$-deficient diseases such as diabetes and MI. Therefore, further study is recommended to investigate the effect of a combination of Se and $\mathrm{Zn}$ in MI. Previous data suggested the potential beneficial antioxidant effects of the combined supplementation of $\mathrm{Zn}$ and $\mathrm{Cr}$ in people with Type 2 diabetes (83). Thus, a combination of $\mathrm{Zn}$ and $\mathrm{Cr}($ pic) 3 could be investigated in future studies to evaluate their synergistic cardioprotective effect. Since our study was focusing on the biochemical and histological alterations, therefore, the evaluation of the cardiac functions including cardiac contractility, left ventricular (LV) systolic and diastolic structure and functions, LV systolic pressure would have added more information regarding the role of Se yeast, $\mathrm{Cr}($ pic) 3 and $\mathrm{Zn}$ in ISO-induced MI. 


\section{CONCLUSION}

In conclusion, pretreatment with selenium, $\mathrm{Cr}($ pic $) 3$ or zinc sulfate exhibits preventive effects on ISOinduced $\mathrm{MI}$ in rats by modulating heart weight, oxidative stress, inflammatory response, NO, lipids, lipoproteins and/or increased the levels of VEGF. The possible mechanism for the overall observed preventive effects of these trace metals may involve antioxidant properties that indirectly help to alleviate the biochemical and morphological alterations in myocardial infarcted tissues. Overall, selenium yeast presented the most cardioprotecrtive effect. Our data also suggest that the appropriate selection of trace metals combination is critical to avoid their interaction or counteracting effects, and consequently to achieve the optimum benefit.

\section{CONFLICT OF INTEREST}

The authors declare that there are no conflicts of interest.

\section{ACKNOLEDGMENT}

This research project was supported by a grant from the 'Research Center for Female Scientific and Medical Colleges', Deanship of Scientific Research, King Saud University.

\section{REFERENCES}

1. Keles MS, Bayir Y, Suleyman H, Halici Z. Investigation of effects of Lacidipine, Ramipril and Valsartan on DNA damage and oxidative stress occurred in acute and chronic periods following isoproterenol-induced myocardial infarct in rats. Mol Cell Biochem, 2009; 328(1-2):109-17.

2. Shaik AH, Rasool SN, Vikram Kumar Reddy A, Abdul Kareem M, Saayi Krushna G, Lakshmi Devi K. Cardioprotective effect of HPLC standardized ethanolic extract of Terminalia pallida fruits against isoproterenol-induced myocardial infarction in albino rats. J Ethnopharmacol, 2012; 141(1):33-40.

3. Sharma HS, Das DK. Role of cytokines in myocardial ischemia and reperfusion. Mediators Inflamm, $6: 175-183$.

4. Li JM, Gall NP, Grieve DJ, Chen M and Shah AM. Activation of NADPH oxidase during progression of cardiac hypertrophy to failure. Hypertension, 2002; 40, 477-484.

5. Doerries $\mathrm{C}$, Grote $\mathrm{K}$, Hilfiker-Kleiner D, Luchtefeld M, Schaefer A, Holland SM, Sorrentino S, Manes C, Schieffer B, Drexler H, Landmesser U. Critical role of the $\mathrm{NAD}(\mathrm{P}) \mathrm{H}$ oxidase subunit p47phox for left ventricular remodeling/dysfunction and survival after myocardial infarction. Circ Res, 2007; 30;100(6):894-903.

6. Heil M, Schaper W. Influence of mechanical, cellular and molecular factors on collateral artery growth (arteriogenesis). Circ Res, 2004; 95: 449458.

7. Lee SH, Wolf PL, Escudero R, Deutsch R, Jamieson SW, Thistlethwaite PA. Early expression of angiogenesis factors in acute myocardial ischemia and infarction. N Engl J Med, 2000; 342: 626-633.

8. Xi L, Jarrett NC, Hess ML, Kukreja RC. Essential role of inducible nitric oxide synthase in monophosphoryl a induced late cardioprotection. Circulation, 1999; 99: 157-163.

9. Dulak J, Jozkowich A, Dembinska-Kiec A, Guevara I, Zdzienicka A, Zmudzinska- Grochot D, Florek I, Wo' jtowicz A, Szuba A, Cooke JP. Nitric oxide induces the synthesis of vascular endothelial growth factor by rat vascular smooth muscle cells. Thromb Vasc Biol, 1999; 20: 659-666.

10. Kane AJ, Barker JE, Mitchell GM, Theile DRB, Romero R, Messina A, Wagh M, Fraulin FOG, MorrisonWA, Stewart AG. Inducible nitric oxide synthase (iNOS) activity promotes ischemic skin flap survival. Br J Pharmacol, 2001; 132: 16311638.

11. Prince PS, Sathya B. Pretreatment with quercetin ameliorates lipids, lipoproteins and marker enzymes of lipid metabolism in isoproterenol treated cardiotoxic male Wistar rats. Eur J Pharmacol, 2010; 635(1-3):142-8.

12. Bor MV, Cevì C, Uslu I, Güneral F, Düzgün E. Selenium levels and glutathione peroxidase activities in patients with acute myocardial infarction. Acta Cardiol, 1999; 54(5):271-6.

13. Kutil B, Ostadal P, Vejvoda J, Kukacka J, Cepova J, Alan D, Krüger A, Vondrakova D. Alterations in serum selenium levels and their relation to troponin I in acute myocardial infarction. Mol Cell Biochem, 2010; 345(1-2):23-7.

14. Panicker S, Swathy SS, John F, Madambath I. Impact of selenium on $\mathrm{NF} \kappa \mathrm{B}$ translocation in isoproterenol-induced myocardial infarction in rats. Biol Trace Elem Res, 2010; 138(1-3):202-2011.

15. Lekakis J, Kalofoutis A. Zinc concentrations in serum as related to myocardial infarction. Clin Chem, 1980; 26:1660-1661.

16. Tan IK, Chua KS, Toh AK. Serum magnesium, copper, and zinc concentrations in acute myocardial infarction. J Clin Lab Anal, 1992; 6:324-328.

17. Arnaud J, Faure H, Bourlard P, Denis B, Favier AE. Longitudinal changes in serum zinc concentration and distribution after acute myocardial infarction. Clin Chim Acta, 1994; 230:147-156.

18. Altekin E, Coker C, Sişman AR, Onvural B, Kuralay F, Kirimli OJ. The relationship between 
trace elements and cardiac markers in acute coronary syndromes. Trace Elem Med Biol, 2005; 18(3):235-42.

19. Afridi HI, Kazi TG, Kazi N, Sirajuddin, Kandhro GA, Baig JA, Shah AQ, Jamali MK, Arain MB, Wadhwa SK, Khan S, Kolachi NF, Shah F. Chromium and manganese levels in biological samples of Pakistani myocardial infarction patients at different stages as related to controls. Biol Trace Elem Res, 2011; 142(3):259-73.

20. Weber KT, Weglicki WB, Simpson RU. Macroand micronutrient dyshomeostasis in the adverse structural remodeling of myocardium. Cardiovasc Res, 2009; 81(3):500-8.

21. Tinggi U. Selenium: its role as antioxidant in human health. Environ Health Prev Med, 2008; 13, 102-108.

22. Vunta H, Belda BJ, Arner RJ, Channa Reddy C, Vanden Heuvel JP, Sandeep Prabhu K. Selenium attenuates pro-inflammatory gene expression in macrophages. Mol Nutr Food Res, 2008; 52(11):1316-23.

23. Kang BP, Bansal MP, Mehta U. Selenium supplementation and diet induced hypercholesterolemia in the rat: changes in lipid levels, malonyldialdehyde production and the nitric oxide synthase activity. Gen Physiol Biophys, 1998; 17(1):71-8.

24. Luoma PV, Sotaniemi EA, Korpela H, Kumpulainen J. Serum selenium, glutathione peroxidase activity and high-density lipoprotein cholesterol--effect of selenium supplementation. Res Commun Chem Pathol Pharmacol, 1984; 46(3):469-72.

25. Stranges S, Marshall JR, Trevisan M, Natarajan R, Donahue RP, Combs GF, Farinaro E, Clark LC, Reid ME. Effects of selenium supplementation on cardiovascular disease incidence and mortality: secondary analyses in a randomized clinical trial. Am J Epidemiol, 2006; 163(8):694-9.

26. Alimohamady R, Aliarabi H, Bahari A, Dezfoulian AH. Influence of different amounts and sources of selenium supplementation on performance, some blood parameters, and nutrient digestibility in lambs. Biol Trace Elem Res, 2013; 154(1):45-54.

27. Thiry C, Schneider YJ, Pussemier L, De Temmerman L, Ruttens A. Selenium bioaccessibility and bioavailability in Se-enriched food supplements. Biol Trace Elem Res, 2013; 152(1):152-60.

28. Liao X, Lu L, Li S, Liu S, Zhang L, Wang G, Li A, Luo X. Effects of selenium source and level on growth performance, tissue selenium concentrations, antioxidation, and immune functions of heat-stressed broilers. Biol Trace Elem Res, 2012;150 (1-3):158-65.

29. Sundaram B, Singhal K, Sandhir R. Antiatherogenic effect of chromium picolinate in streptozotocin-induced experimental diabetes. J Diabetes, 2013; 5(1):43-50.

30. Sundaram B, Aggarwal A, Sandhir R. Chromium picolinate attenuates hyperglycemia-induced oxidative stress in streptozotocin-induced diabetic rats. J Trace Elem Med Biol, 2013; pii: S0946672X(12)00125-3.

31. Mozaffari MS, Abdelsayed R, Liu JY, Wimborne H, El-Remessy A, El-Marakby A. Effects of chromium picolinate on glycemic control and kidney of the obese Zucker rat. Nutr Metab, 2009; 10:6:51.

32. Sahin K, Tuzcu M, Orhan C, Gencoglu H, Ulas M, Atalay M, Sahin N, Hayirli A, Komorowski JR. The Effects of Chromium Picolinate and Chromium Histidinate Administration on NF- $\kappa \mathrm{B}$ and Nrf2/HO-1 Pathway in the Brain of Diabetic Rats. Biol Trace Elem Res, 2012;150(1-3):291-6.

33. Selcuk MY, Aygen B, Dogukan A, Tuzcu Z, Akdemir F, Komorowski JR, Atalay M, Sahin K. Chromium picolinate and chromium histidinate protects against renal dysfunction by modulation of NF- $\kappa$ B pathway in high-fat diet fed and Streptozotocin-induced diabetic rats. Nutr Metab, 2012; (Lond) 8:9:30.

34. Jain SK, Rains JL, Croad JL. Effect of chromium niacinate and chromium picolinate supplementation on lipid peroxidation, TNF-alpha, IL-6, CRP, glycated hemoglobin, triglycerides, and cholesterol levels in blood of streptozotocin-treated diabetic rats. Free Radic Biol Med, 2007; 43(8):1124-31.

35. Press RI, Geller J, Evans GW. The effect of chromium picolinate on serum cholesterol and apolipoprotein fractions in human subjects. West $\mathbf{J}$ Med, 1990; 152(1):41-5.

36. Abebe W, Liu JY, Wimborne H, Mozaffari MS. Effects of chromium picolinate on vascular reactivity and cardiac ischemia-reperfusion injury in spontaneously hypertensive rats. Pharmacol Rep, 2010; 62(4):674-82.

37. Moore JW, Maher MA, Banz WJ, Zemel MB. Chromium picolinate modulates rat vascular smooth muscle cell intracellular calcium metabolism. J Nutr, 1998; 128: 180-184.

38. Bao B, Prasad AS, Beck FW, Fitzgerald JT, Snell D, Bao GW, Singh T, Cardozo LJ. Zinc decreases C-reactive protein, lipid peroxidation, and inflammatory cytokines in elderly subjects: a potential implication of zinc as an atheroprotective agent. Am J Clin Nutr, 2010; 91: 1634 -1641.

39. Suntres ZE, Lui EM. Antioxidant effect of zinc and zinc-metallothionein in the acute cytotoxicity of hydrogen peroxide in Ehrlich ascites tumour cells. Chem Biol Interact, 2006; 162: 11-23.

40. Zaitone SA, Abo-Gresha NM. Rosuvastatin promotes angiogenesis and reverses isoproterenolinduced acute myocardial infarction in rats: Role of iNOS and VEGF. Eur J Pharmacol, 2012; 691(13):134-42. 
41. Kesik V, Lenk MK, Kurekci AE, Acikel CH, Akgul EO, Aydin A, Erdem O, Gamsizkan M. Do zinc and selenium prevent the antioxidant, hepatic and renal system impairment caused by aspirin in rats? Biol Trace Elem Res, 2008; 123(1-3):168-78.

42. He X, Hong X, Zeng F, Kang F, Li L, Sun Q. Zinc antagonizes homocysteine induced fetal heart defects in rats. Cardiovasc Toxicol, 2009; 9: 151159.

43. Chan HM, Tabarrok R, Tamura Y, Cherian MG. The relative importance of glutathione and metallothionein on protection of hepatotoxicity of menadione in rats. Chem Biol Interact, 1992; 84(2):113-24.

44. Di Leo V, D'Incà R, Barollo M, Tropea A, Fries W, Mazzon E, Irato P, Cecchetto A, Sturniolo GC. Effect of zinc supplementation on trace elements and intestinal metallothionein concentrations in experimental colitis in the rat. Dig Liver Dis, 2001; 33(2):135-9.

45. Ahmad A, Khan MM, Ishrat $\mathrm{T}$, Khan MB, Khuwaja G, Raza SS, Shrivastava P, Islam F. Synergistic effect of selenium and melatonin on neuroprotection in cerebral ischemia in rats. Biol Trace Elem Res, 2011; 139(1):81-96.

46. Yousuf S, Atif F, Ahmad M, Hoda MN, Khan MB, Ishrat $\mathrm{T}$, Islam $\mathrm{F}$. Selenium plays a modulatory role against cerebral ischemia-induced neuronal damage in rat hippocampus. Brain Res, 2007; 1147:218-25.

47. El-Shenawy SM, Hassan NS. Comparative evaluation of the protective effect of selenium and garlic against liver and kidney damage induced by mercury chloride in the rats. Pharmacol Rep, 2008; 60(2):199-208.

48. Ishrat $\mathrm{T}$, Parveen K, Khan MM, Khuwaja G, Khan MB, Yousuf S, Ahmad A, Shrivastav P, Islam F. Selenium prevents cognitive decline and oxidative damage in rat model of streptozotocin-induced experimental dementia of Alzheimer's type. Brain Res, 2009; 1281:117-27.

49. Anderson RA, Bryden NA, Polansky MM. Lack of toxicity of chromium chloride and chromium picolinate in rats. J Am Coll Nutr, 1997; 16(3):2739.

50. Ohkawa H, Ohishi N, Yagi K. Assay for lipid peroxides in animal tissues by thiobarbituric.acid reaction. Anal Biochem, 1979; 95: 351-58.

51. Moron MS, Depierre J, Mannervik B. Levels of glutathione, glutathione reductase and glutathione S- transferase activities in rat lung and liver. Biochem Biophys Acta, 1979; 582: 67-78.

52. Aebi H. Methods of enzymatic analysis, Bergmayer HU, $2^{\text {nd }}$ edition, pp 673-684, 1974.

53. Green L, Wagner D, Glogowski J, Skipper P, Wishnok J, Tannenbaum S. Analysis of nitrate, nitrite and $[15 \mathrm{~N}]$ nitrate in biological fluids. Anal Biochem, 1982; 126: 131-138.

54. Nirmala C, Puvanakrishnan R. Protective role of curcumin against isoproterenol induced myocardial infarction in rats. Mol Cell Biochem, 1996; 159:85-3.

55. DiSilvestro RA. Zinc in relation to diabetes and oxidative stress. J Nutr, 2000; 130 :1509S- 1511S.

56. Tanguy S, Rakotovao A, Jouan MG, Ghezzi C, de Leiris J, Boucher F. Dietary selenium intake influences Cx43 dephosphorylation, TNF- $\alpha$ expression and cardiac remodeling after reperfused infarction. Mol Nutr Food Res, 2011; 55(4):522-9.

57. Lymbury RS, Marino MJ, Perkins AV. Effect of dietary selenium on the progression of heart failure in the ageing spontaneously hypertensive rat. Mol Nutr Food Res, 2010; 54: 1436-1444.

58. Prabhu KS, Zamamiri-Davis F, Stewart JB, Thompson JT, Sordillo LM, Reddy CC. Selenium deficiency increases the expression of inducible nitric oxide synthase in RAW 264.7 macrophages: role of nuclear factor-kappaB in up-regulation. Biochem J, 2002; 366(Pt 1):203-9.

59. Holben DH and Smith AM. The diverse role of selenium within selenoproteins: a review. J Am Diet Assoc, 1999; 99: 836-843.

60. Murray DR, Prabhu SD, Chandrasekar B. Chronic $\beta$-adrenergic stimulation induces myocardial proinflammatory cytokine expression, Circulation, 2000; $1012338-2341$.

61. Chandrasekar B, Marelli-Berg FM, Tone M, Bysani S, Prabhu SD, Murray DR. Beta-adrenergic stimulation induces interleukin-18 expression via beta2-AR PI3K, Akt, IKK and NF-kappa B, Biochem. Biophys. Res. Commun, 2004; 319: 304311.

62. Panicker S, Swathy SS, John F, M I. Impact of selenium on the leukotriene B4 synthesis pathway during isoproterenol-induced myocardial infarction in experimental rats. Inflammation, 2012; 35(1):7480 .

63. Karam R, Healy BP, Wicker P. Coronary reserve is depressed in postmyocardial infarction reactive cardiac hypertrophy. Circulation, 1990; 81: 238246.

64. Freedman SB, Isner JM. Therapeutic angiogenesis for ischemic cardiovascular disease. J Mol Cell Cardiol, 2001; 33: 379-393.

65. Bajpai S, Mishra M, Kumar H, Tripathi K, Singh SK, Pandey HP, Singh RK. Effect of selenium on connexin expression, angiogenesis, and antioxidant status in diabetic wound healing. Biol Trace Elem Res, 2011; 144(1-3):327-38.

66. Liu JG, Zhao HJ, Liu YJ, Wang XL. Effect of selenium-enriched malt on VEGF and several relevant angiogenic cytokines in diethylnitrosamine-induced hepatocarcinoma rats. J Trace Elem Med Biol, 2010; 24(1):52-7.

67. Liu JG, Zhao HJ, Liu YJ, Liu YW, Wang XL. Effect of two selenium sources on hepatocarcinogenesis and several angiogenic cytokines in diethylnitrosamine-induced 
hepatocarcinoma rats. J Trace Elem Med Biol, 2012; 26(4):255-61.

68. Lau YT, Ma WC. Nitric oxide inhibits migration of cultured endothelial cells. Biochem Biophys Res Commun, 1996; 221: 670-674.

69. Pipili-Synetos E, Sakkoula E, Haralabopoulos G. Evidence that nitric oxide is an endogenous antiangiogenic mediator. Br J Pharmacol, 1994; 111: 894-902.

70. Coleman JW. Nitric oxide in immunity and inflammation. Int Immunopharmacol, 2001; 1: 1397-1406.

71. Ostadalova I, Vobecky M, Chvojkova Z, Mikova D, Hampl V, Wilhelm J, Ostadal B. Selenium protects the immature rat heart against ischemia/reperfusion injury. Mol Cell Biochem, 2007; 300(1-2):259-67.

72. Atakisi O, Atakisi E, Kart A. Effects of dietary zinc and L-arginine supplementation on total antioxidants capacity, lipid peroxidation, nitric oxide, egg weight, and blood biochemical values in Japanese quails. Biol Trace Elem Res, 2009; 132(13):136-43.

73. Vennila L, Pugalendi KV. Efficacy of sesamol on plasma and tissue lipids in isoproterenol-induced cardiotoxicity in wistar rats.Arch Pharm Res, 2012; 35(8):1465-70.

74. Nagoor Meeran MF, Stanely Mainzen Prince P, Hidhayath Basha R. Preventive effects of N-acetyl cysteine on lipids, lipoproteins and myocardial infarct size in isoproterenol induced myocardial infarcted rats: an in vivo and in vitro study. Eur $\mathrm{J}$ Pharmacol, 2012; 677(1-3):116-22.

75. Devika PT, Stanely Mainzen Prince P. Preventive effect of (-)epigallocatechin gallate on lipids, lipoproteins, and enzymes of lipid metabolism in isoproterenol-induced myocardial infarction in rats. J Biochem Mol Toxicol, 2009; 23(6):387-93.

76. Yudkin JS, Stehouwer CD, Emeis JJ et al. Creactive protein in healthy subjects: associations with obesity, insulin resistance, and endothelial dysfunction: a potential role for cytokines originating from adipose tissue? Arterioscler Thromb Vasc Biol, 1999; 19:972-978.
77. Rosenstock M, Greenberg AS, Rudich A. Distinct long-term regulation of glycerol and non-esterified fatty acid release by insulin and TNF-alpha in 3T3L1 adipocytes. Diabetologia, 2001; 44:55-62.

78. Wasan KM, Ng SP, Wong W, Rodrigues BB. Streptozotocin- and alloxan-induced diabetes modifies total plasma and lipoprotein lipid concentration and composition without altering cholesteryl ester transfer activity, Pharmacol Toxicol, 1998; 83(4):169-75.

79. Yoshizawa K, Ascherio A, Morris JS, Stampfer MJ, Giovannucci E, Baskett CK, Willett WC, Rimm EB. Prospective study of selenium levels in toenails and risk of coronary heart disease in men. Am J Epidemiol, 2003; 158(9):852-60.

80. Gromadzińska J, Wasowicz W, Sklodowska M, Bulikowski W, Rydzyński $\mathrm{K}$. The influence of atmospheric chromium on selenium content and glutathione peroxidase activity in blood of tannery workers. Environ Health Perspect, 1996; 104(12):1312-6.

81. Schrauzer GN. Interactive effects of selenium and chromium on mammary tumor development and growth in MMTV-infected female mice and their relevance to human cancer. Biol Trace Elem Res, 2006; 109(3):281-92.

82. Fatmi W, Kechrid Z, Nazıroğlu M, Flores-Arce M. Selenium supplementation modulates zinc levels and antioxidant values in blood and tissues of diabetic rats fed zinc-deficient diet. Biol Trace Elem Res, 2013; 152(2):243-50.

83. Anderson RA, Roussel AM, Zouari N, Mahjoub S, Matheau JM, Kerkeni A. Potential antioxidant effects of zinc and chromium supplementation in people with type 2 diabetes mellitus. J Am Coll Nutr, 2001; 20(3):212-8. 